\title{
Media Coverage and the Cost of Debt
}

\author{
Haoyu Gao, Junbo Wang ${ }^{\circledR}$, Yanchu Wang, Chunchi Wu, \\ and Xi Dong*
}

\begin{abstract}
This paper investigates the relation between media coverage and offering yield spreads using a comprehensive dataset of 5,338 industrial bonds issued from 1990 to 2011 . We find that media coverage is negatively associated with firms' cost of debt. This association is robust to controlling for standard yield determinants, different model specifications, and endogeneity. We identify 4 economic channels through which media coverage influences the cost of debt: Information asymmetry, governance, liquidity, and default risk. Importantly, media coverage has an independent influence beyond the effects of these economic mechanisms and is not a proxy for other firm attributes.
\end{abstract}

\section{Introduction}

In a market with information frictions, providing corporate information to market participants through timely dissemination to a broad investor base can have important implications for market efficiency, liquidity, and asset pricing (see Bushee, Core, Guay, and Hamm (2010), Peress (2014)). The media play a key role in generating and disseminating information to a large population of investors. Through verification, comparison, reliability assessment, and integration of information from multiple data sources, the media can generate information that has significant economic value, alleviate information frictions, and improve investor

\footnotetext{
*Gao, gaohaoyu@ cufe.edu.cn, Renmin University of China Hanqing Advanced Institute of Economics and Finance; J. Wang (corresponding author), jwang2@ cityu.edu.hk, City University of Hong Kong Department of Economics and Finance; Y. Wang, wang.yanchu@mail.shufe.edu.cn, Shanghai University of Finance and Economics and Shanghai Institute of International Finance and Economics; Wu, chunchiw@buffalo.edu, State University of New York at Buffalo School of Management; and Dong, xi.dong@baruch.cuny.edu, Baruch College Department of Economics and Finance. The authors thank Justin Birru and participants at the 2016 China International Conference in Finance for their helpful comments. We are grateful to Paul Malatesta (the editor) and Ron Masulis (the referee) for their valuable comments and suggestions that have helped improve our paper significantly. We also thank Kee H. Chung, Qianqian Huang, and Jack Jiang for sharing data. Gao acknowledges financial support from the National Science Foundation of China (No. 71702207). J. Wang acknowledges financial support from a City University Strategic Research Grant (Project 7004979 and 7004712) and a research grant from the National Science Foundation of China (No. 71528001 and 71720107002). Y. Wang acknowledges financial support from Innovative Research Team of Shanghai University of Finance and Economics (No. 2014110345).
} 
recognition and assessment of securities. This can then increase a firm's shareholder base and trading activity. Past studies have found that the breadth of information dissemination by the media affects stock valuation and risk premiums (Fang and Peress (2009), Peress (2014)). Stocks heavily covered by the media have significantly lower expected returns than stocks that are poorly covered. This evidence suggests that media coverage can significantly reduce the cost of equity capital by improving a firm's information environment, investor recognition, and market liquidity.

Existing studies on the effects of media coverage have focused on stocks, investment funds, and initial public offerings (IPOs) in the equity market (see, e.g., Dyck and Zingales (2003), Fang and Peress (2009), Bushee et al. (2010), Solomon, Soltes, and Sosyura (2014), Liu, Sherman, and Zhang (2014), Dai, Parwada, and Zhang (2015), Al Guindy (2016), Hillert and Ungeheuer (2016), and Baloria and Heese (2018)). The role of the media in bond pricing, however, remains unexplored. Thus, little is known about the relation between media coverage and the cost of debt. This paper provides new evidence on the relationship between media coverage and the cost of debt capital, as well as on the channels through which media coverage works.

In a capital market with imperfections, a premium is generally required to compensate for investor participation. Merton's (1987) classical investor-based theory suggests that in an incomplete market, investors only possess information for a limited number of securities. As a consequence, they invest only in a subset of securities, which results in the imperfect diversification of their investments. Securities that have a lower investor base must therefore offer a higher premium to compensate investors for suboptimal diversification. Likewise, as investor knowledge of investment opportunities depends on information availability, securities with less available information should offer a higher premium to attract uninformed investors (Rock (1986), Easley and O'Hara (2004)).

The media collect, select, verify, interpret, integrate, repackage, and distribute information about firm fundamentals from a variety of sources, such as company press releases, public relations departments, managers, analysts, and other market participants (Dyck, Volchkova, and Zingales (2008), Fang and Peress (2009)). Due to their ability to integrate, package, and spread information broadly, the media have become an increasingly important information integrator, validator, and disseminator. By disseminating information to a broad audience, the media play a critical role in broadening investor recognition and reducing information asymmetry, thereby exerting a significant influence on stock market performance. Dyck and Zingales (2003) examine stock price reactions to earnings announcements reported by the press and find that the impact of media coverage on stock prices is larger when investors have fewer alternative sources of information. Fang and Peress (2009) find that media coverage explains the cross-sectional variation in expected stock returns. Tetlock (2007) and Tetlock, Saar-Tsechansky, and Macskassy (2008) investigate the linguistic content of news articles and find that the tone of media coverage affects stock prices. Peress (2014) shows that media coverage contributes to the efficiency of the stock market by improving the dissemination of information among investors, and its incorporation into stock prices. 
One question of fundamental importance is whether media coverage of a firm is relevant for corporate bond pricing. Corporate bonds and stocks are both contingent claims on the same firm's assets. If media coverage is relevant to firm value, it would have a potential effect on both stock and bond prices. It is well known that individual investors in the corporate bond market do not have the same access to information as in the stock market. ${ }^{1}$ If the media alleviate informational frictions for firms and investors, coverage would benefit bond investors more than stock investors, as the bond market is more opaque than the stock market. Therefore, if the media reduce information asymmetry and risk premiums, these benefits would potentially be greater for corporate bonds, ceteris paribus. Besides reducing information asymmetry, media coverage can influence a firm's corporate governance (Dyck et al. (2008)), liquidity (Diamond and Verrecchia (1991)), and default risk premiums (Duffie and Lando (2001)) by exposing its governance problems, increasing its trading activity, and improving the information environment. Thus, the effect of media coverage can work through the channels of information asymmetry, governance, liquidity, and default risk.

Using a comprehensive data set that includes a large number of corporate bonds issued over a long time span, we document extensive evidence that media coverage is negatively related to the cost of debt. This evidence is robust to controls for firm/bond attributes, model specifications, potential nonlinearity, and endogeneity. Firms covered by the media have significantly lower offering yield spreads on bonds than those not covered. This finding is consistent with our contention that public information dissemination alleviates information frictions and broadens investor recognition, thereby lowering bond premiums. The negative relation between media coverage and the cost of debt is economically significant. On average, offering yield spreads for bonds issued by firms not covered by the media are 133 basis points higher than for those heavily covered by the media. This negative relation remains significant even after further controlling for the effects of term structure and capital structure variables, alternative information sources, corporate governance, liquidity, and default risk. Results strongly suggest that media coverage is not a proxy for these variables.

To investigate the economic channels through which media coverage impacts corporate debt, we examine firms with diverse characteristics and debt attributes. Dyck and Zingales (2003) suggest that the fewer alternative sources of information that exist for a company, the more demand for information and the greater the impact of media coverage. Consistent with this prediction, we find that the relationship between media coverage and bond offering yields is stronger for firms with a smaller analyst following, lower institutional ownership, and affiliation with less reputable investment banks. Small firms are opaque and have higher information asymmetry, as are young firms that have recently gone public. Also, accounting information is less reliable for firms with high discretionary accruals. In line with information demand theory, we find that the impact of media coverage is much greater for these firms. Our results strongly support the hypothesis that a

\footnotetext{
${ }^{1}$ As Arthur Levitt, the past chairman of the U.S. Securities and Exchange Commission, stated, "The sad truth is that investors in the corporate bond market do not enjoy the same access to information as a car buyer or a home buyer or, I dare say, a fruit buyer" (Wall Street Journal, Oct. 9, 1998).
} 
fundamental economic mechanism underlying the impact of media coverage on the cost of debt capital is an improved firm information environment.

Empirical evidence also reveals that an important channel through which media coverage works is its influence on corporate governance. We document a significant positive interaction effect between media coverage and corporate governance, which reflects the ability of media to improve management oversight and efficiency. Moreover, we uncover two additional important channels through which the media coverage has an impact on bond yield spreads, namely bond liquidity and default risk. Our results show that the impact of media coverage is greater for firms with lower bond and stock liquidity, and higher default risk.

The negative association between media coverage and bond offering yield spreads could be induced by endogeneity. For example, firms may take steps to encourage and increase media coverage before a bond offering. Endogeneity can result in inconsistency and biased empirical estimates. We employ several conventional approaches to address this concern. First, we use propensity score matching (PSM) to identify "twin" firms that have an equal likelihood of incurring media coverage, and compare the cost of debt for these firms in our characteristicmatched sample. Our conclusion for the relationship between media coverage and the cost of debt is virtually unchanged, even with stringent controls for matching firm characteristics. Second, we use the number of news reporters located in the headquarter state as an instrumental variable for the supply of local media, perform a 2-stage regression to address the potential endogeneity problem, and obtain a consistent parameter estimate of media coverage. Results continue to show that media coverage has a significant negative relation to the cost of debt. Third, we use lagged (predetermined) media coverage and an orthogonal media coverage measure that extracts other media coverage determinants as alternative explanatory variables, and controls for issuer-fixed effects. We find that the results are robust to these specification changes. Lastly, we employ a Heckman's (1979) selection model to correct the potential bias in the regression estimation, and again our inference for the role of media coverage remains unchanged.

There is a growing body of literature on the role of media coverage in asset pricing and corporate decisions. Our paper expands this literature by exploring the information dissemination and processing/integration roles of media in the cost of debt financing. Understanding the role of information dissemination in the valuation of bonds is important. First and foremost, the corporate bond market is the primary source of long-term capital in the U.S. (Bhojraj and Sengupta (2003)). ${ }^{2}$ In terms of the amount of capital raised, the debt market is much larger than the stock market. Second, unlike equity, the costs of debt and bond risk premiums are better defined and easier to measure (Dhaliwal, Hogan, Trezevant, and Wilkins (2011)). Expected returns on bonds or the cost of debt can be measured more precisely by yield spreads, whereas the estimation of the cost of equity capital relies upon beta estimates, which contain substantial noise. Corporate bonds thus

\footnotetext{
${ }^{2}$ For example, the Securities Industry and Financial Markets Association (SIFMA) 2014 Report shows that the total capital proceeds from all equity issues is 100.7 billion dollars, while the amount from corporate bond issues is 1,430.6 billion dollars. The debt market is even more important if we consider bank loans and other private debts.
} 
offer an attractive setting for studying the relationship between media coverage and the cost of capital. Findings for the corporate bond market can therefore provide stronger support for the effects of media coverage. Third, the bond market has a different investor clientele than the stock market (Cai, Helwege, and Warga (2007)). Different investors possess different information sets and may develop distinct reactions to media information. From the investor's perspective, it is important to understand the potential effect of media information dissemination on bond prices. Understanding the influence of information dissemination on the cost of debt also aids firms in making financing decisions. A practical implication of our findings is that financial managers may be able to lower a firm's cost of debt by devoting more efforts to improving their media relations and coverage.

By investigating the role of media coverage in debt financing, this paper contributes to the current literature in a number of ways. First, to our knowledge, this paper is the first to document that media coverage can exert a significant economic impact on debt offerings. Our finding is consistent with several recent studies, which suggest that an improvement in the firm's information environment decreases credit spreads (see Andrade, Bernile, and Hood (2014), Cassar, Ittner, and Cavalluzzo (2014)).

Second, this paper improves our understanding of the determinants of media coverage in the bond market. We show that besides widely used firm and bond characteristics, board quality, investment bank and auditor reputation, the size and reputation of loan syndicates, past bond offerings, liquidity, and number of shareholders and employees all influence the media coverage of debt issuing firms. Third, we uncover evidence that the impact of media coverage works in part through the information asymmetry, corporate governance, liquidity, and default risk channels. More importantly, we show that media coverage exerts an independent influence over and beyond the effects of these economic channels and traditional determinants of bond yields.

Finally, we find that media coverage is negatively related to public debt flotation costs. This relation is robust to controlling for underwriter and auditor quality, the size and reputation of loan syndicates, bond issue size, rating, and other standard determinants of underwriting fees. This finding offers a new perspective on the information role of media coverage in capital markets.

The rest of the paper is organized as follows: Section II proposes the main hypotheses tested in this paper. Section III describes the sample selection procedure and the variables used in our empirical tests. Section IV analyzes the determinants of media coverage. Section V examines the relation between media coverage and the cost of debt, investigates the channels through which the potential media effect works, and explores the relation between flotation costs and media coverage. Section VI conducts additional tests and robustness checks. Finally, Section VII summarizes the main findings and concludes the paper.

\section{Hypothesis Development}

Existing theory suggests that a firm's information environment affects the valuation of its securities (see Merton (1987), Diamond and Verrecchia (1991), Rock (1986), and Easley and O'Hara (2004)). Most theoretical models reach a 
conclusion that firms with a poorer information environment will have lower security values and higher costs of capital. An implication of this theory is that any system capable of changing the firm's information environment will have a potential impact on security valuation and the cost of capital.

The media play a central role in producing and disseminating information. Media actively engage in information production through the verification of information, comparison and reliability assessments of news sources, and the integration of information drawn from multiple data sources. By producing and disseminating quality information to the public, the media can improve a firm's information environment and reduce information asymmetry, thereby lowering the information risk premium and the cost of capital. Better firm information also expands a firm's investor base by making a security more attractive to own and increasing its trading activity. Studies on the role of the business press in the equity market have shown that the media can reduce information costs, increase stock value (Chan (2003), Fang (2005), and Tetlock (2007)), and reduces the cost of equity capital (Fang and Peress (2009)). As bonds and stocks are claims for the same underlying assets of the firm, information dissemination by the media should benefit the pricing not only of stocks, but also bonds, as a firm's information environment improves. Thus, media coverage can potentially reduce the cost of debt capital. This leads to the first hypothesis we test in this paper.

Hypothesis 1. By alleviating information frictions, media coverage can help reduce a firm's cost of debt. Firms with higher media coverage can thus issue bonds at lower yield spreads.

The ability of media coverage to lower the cost of capital through reducing information asymmetry, referred to as the information asymmetry channel in this paper, generally depends on the type and variety of information sources available to investors. When fewer alternative sources of information are available about a firm and its competitors, investors have a higher demand for information and the potential impact of media coverage is greater (see Dyck and Zingales (2003)). Information availability varies across firms, and depends on both external and internal factors. The firm's external sources of information include information intermediaries such as financial analysts, investment banks, commercial banks, auditors, and institutional investors.

Financial analysts gather information about firms from a variety of sources, including financial disclosures, company press releases, industry and competitor news, and earnings conference calls, as well as interactions with firm management and brokerage clients. As part of this process, analysts produce reports which convey information about the prospects of a firm's future performance. With more information available, information asymmetry for a firm's investors is lower, especially when more analysts follow the firm.

Investment banks provide information to capital market participants. These financial intermediaries have strong incentives to deliver quality information to investors, as they want the offerings they underwrite to succeed so that they can build their reputation and improve their opportunities to manage more underwriting business in the future. Reputable investment banks are better able to assess issue quality and reduce information asymmetry. Fang (2005) finds that reputable 
underwriters help reduce information asymmetries between investors and the issuers, and their underwriting decisions are informative of issue quality. The investment banking certification literature has also shown that investment banks benefit from correctly certifying IPO firm quality (see Dunbar (2000)), and suffer losses in clients and market share when they certify poorly. Due to reputation concerns, the creditability of information issued by reputable banks tends to be higher. $\mathrm{Au}$ ditors perform a similar function of conveying credible information by providing independent verification of the financial statements prepared by managers. Past studies have shown that hiring auditors with a stronger reputation reduces the cost of debt by decreasing information asymmetry (Mansi, Maxwell, and Miller (2004), Pittman and Fortin (2004)).

Institutional investors also play an information role in financial markets. Institutional holdings reduce information asymmetry that would otherwise adversely affect firm value (Healy, Hutton, and Palepu (1999), Bushee and Noe (2000)). By pressing management to disclose more information, institutional investors help improve the firm's information environment and reduce the cost of information gathering. Institutional investors can also gather information themselves and reveal their proprietary information through their trading activities. Both efforts reduce the informational advantages of management and lower information risk to investors. Boone and White (2015) find that higher institutional ownership is associated with greater management disclosure and analyst following, thereby lowering information asymmetry.

As media play an information dissemination role similar to information intermediaries, the services provided by these agents may overlap with each other. Articles published by a media outlet have greater impact if a firm is covered exclusively by that outlet than if there are other intermediaries providing similar information about the same firm. Thus, the impact of media coverage is expected to be stronger when investors have fewer alternative sources of information.

In addition to external sources, firms disclose information to outside investors. As smaller firms provide less information, information asymmetry is higher for these firms, making it more difficult for investors to evaluate their future prospects. Stiglitz and Weiss (1981) suggest that information frictions are higher for small firms, and the economic impacts of information asymmetry on these firms are greater. Easley and O'Hara (2004) show that information asymmetry has a greater impact on the cost of capital for firms with less publicly available information, which are typically small and young firms little known to the public. For these firms, information uncertainty is also high (Chen, DeFond, and Park (2002), Zhang (2006)). Fang and Peress (2009) find that the effect of media coverage on stock prices is stronger for small firms that have lower investor recognition and fewer analysts following their operation.

Firms vary in their accounting information quality. Those with large accruals and intangible assets tend to have less reliable accounting information. Media coverage will provide more benefits and have larger impacts on these firms. In addition, firms with a recent IPO are typically young and small, and have high information asymmetry that falls with seasoning. We expect the impact of media coverage on such firms to be stronger, given the evidence on post-IPO CEO performance (Pan, Wang, and Weisbach (2015)) and evidence of stock seasoning 
over the first few years after an IPO when stock return volatility declines (Barth, Landsman, and Taylor (2017)). ${ }^{3}$

In sum, the effectiveness of media coverage in reducing information asymmetry depends on the availability of other information sources, the size and maturity of the firm receiving coverage, and the reliability of accounting information for a given firm. The preceding analysis leads to our second hypothesis, which is linked to the information asymmetry channel of the media impact.

Hypothesis 2. The marginal impact of media coverage on the cost of debt is greater when information asymmetry is higher. The media impact is larger if a firm has a smaller analyst following, lower institutional ownership, less reputable investment bankers, a recent IPO, smaller equity capitalization, younger age, and lower accounting information quality.

Besides their information dissemination role, the media play a governance role (Dyck and Zingales (2002), Liu and McConnell (2013)). Media are not only the vehicles for advertising and reporting firm activities, but are also active agents, conveying strategic tone through editorials and feature articles. The information propagated by the media to the public shapes a firm's reputation and image (Fombrun and Shanley (1990), Deephouse (2000)). Media information production can often tip off large shareholders, institutional shareholders, outside directors, and especially independent directors, to problems within the firm as well as to news about competitors that can have important implications for this firm. Media coverage can thus improve a firm's governance and performance. We refer to this mechanism as the governance channel.

The media can enhance corporate governance in several ways. First, by reducing information asymmetry, the media attenuate insider information advantages and reduce their incentives to exploit shareholders and bondholders. Second, by exposing the governance problems of poorly managed firms, the media can discipline managers and directors (Dyck, Morse, and Zingales (2010)). Media exposure of board ineffectiveness can force the targeted agents to take corrective actions in part by putting downward pressure on the firm's securities. This in turn raises the attractiveness of the firm as a takeover target. Past studies find that firms with ineffective boards are pressured to take observable steps to improve their board quality following negative exposure by the media (Joe, Louis, and Robinson (2009)). Additionally, public information can alert large shareholders and board members to management problems which are then likely to be addressed quickly. This is because dissemination of news on the poor performance of executives adversely affects their personal wealth and reputation capital. It has been shown that reputation-building is a powerful source of discipline, and media pressure is an effective deterrent against corporate fraud (Dyck et al. (2008)). Thus, the media can play a positive role in corporate governance.

The literature has shown that firms with better corporate governance have lower costs of debt (Anderson, Mansi, and Reeb (2004), Fields, Fraser, and Subrahmanyam (2012)). This finding suggests that the media's role in enhancing

${ }^{3}$ We thank the referee for providing this insightful suggestion. 
corporate governance represents an economic channel through which media coverage can potentially decrease the cost of debt. This leads to the following hypothesis.

Hypothesis 3. The media play a positive role in corporate governance by improving management oversight and efficiency and thereby reducing the cost of debt. Media coverage leads to improved board governance and lower yield spreads, resulting in an interaction impact of media coverage and corporate governance performance that consequently lowers the cost of debt capital.

Media coverage can also affect firm liquidity and default risk premiums. Diamond and Verrecchia (1991) show that information dissemination reduces information asymmetry, raising securities' attractiveness to investors, and encouraging greater trading activity, thereby increasing liquidity. Duffie and Lando (2001) suggest that poor information environments and less reliable accounting information increase default risk premiums.

Bushee et al. (2010) and Blankespoor, Miller, and White (2014) provide evidence that the media mitigate the problem of asymmetric information, resulting in lower bid-ask spreads and higher order depth. Boone and White (2015) also find that lower information asymmetry leads to higher liquidity for the firm. On the flip side, illiquid firms have higher information frictions and thus, information demand is higher for these firms. Tetlock (2010) finds that media coverage has a much greater impact on illiquid firms. Information production is also much more costly and time consuming for firms with lower liquidity, as these firms are also less transparent. Past studies suggest that the marginal benefit of information production is larger for firms with limited information provision and less reliable information (Grossman and Stiglitz (1980), Chung, McInish, Wood, and Wyhowski (1995), Veldkamp (2006), and Vlastakis and Markellos (2012)). Thus, by disseminating news, media coverage potentially has a greater impact on less liquid firms.

A firm's information environment also affects its default risk premium. Yu (2005) finds that a poor information environment increases bond yields. Firms with high information frictions also have low liquidity, which raises their interest cost. Higher interest increases a firm's financial burden and default risk. Thus, by improving a firm's information environment, media coverage can potentially reduce its default risk premium and the cost of borrowing. Moreover, by disseminating information, the media plays a role in deterring corporate fraud and malfeasance (Dyck et al. (2008)), which also decreases the risk of firm default. As the benefit of information production is greater for opaque firms, the effect of media coverage on yield spreads of bond issues is expected to be greater for firms with higher default risk or greater opacity.

To summarize, as information dissemination improves the firm's information environment, media coverage increases liquidity and decreases default risk premiums. Media coverage can therefore work through the channels of liquidity and default risk to lower bond yield spreads. Since the marginal benefit of media coverage is larger for firms with lower liquidity and higher default risk, which also tend to be more opaque, the impact of media coverage is expected to be greater for these firms. This motivates the next hypothesis below. 
Hypothesis 4. The production and dissemination of media information increases firm liquidity and decreases default risk, thereby reducing the cost of debt capital. This potential effect is larger for firms with lower liquidity and higher default risk, more opaque firms and firms with less reliable accounting statements.

By disseminating information to investors, media coverage can also affect flotation costs of bond underwriting. An important function performed by underwriters is providing quality information to investors. Because of their ability to better assess issue quality, underwriters provide a valuable service to reduce information asymmetry. As media perform a similar function of reducing information asymmetry, media coverage can potentially reduce the need for underwriting services and exert a downward pressure on underwriting fees. This leads to the following hypothesis.

Hypothesis 5. By alleviating information asymmetry, media coverage can exert a downward pressure on flotation costs. Firms with higher media coverage are expected to have lower flotation costs of debt.

The analysis above suggests that the media have the potential to reduce the cost of debt by disseminating information to lower information frictions, improve corporate governance, increase the firm's investor base and trading activity, and decrease its default risk. As such, the effect of media dissemination can work through the channels of information asymmetry, governance, liquidity, and default risk. Moreover, media coverage can potentially reduce flotation costs of bond underwriting. While these channels may not be mutually exclusive, finding evidence in support of these economic channels can provide an affirmation that media coverage has a real effect on firm financing costs.

\section{Data}

\section{A. Sample Description}

Data for corporate bond issues and underwritings are collected from the Thomson Financial Securities Data Company (SDC) database, which offers detailed issuance information. To measure issuer-level media exposure, we search the LexisNexis database for the number of newspaper articles written about each firm. This database contains monthly reports of news coverage. ${ }^{4}$ For bonds issued between Jan. 1990 and Jan. 2011, we first remove those issued by financial and utility firms, as these bonds behave differently from regular bonds. We also filter out observations with obvious data recording errors. To avoid confounding effects associated with embedded options, we exclude convertible, callable, and exchangeable bonds, and focus on straight bonds with fixed coupon rates. Further, we eliminate bonds with missing rating information in the FISD (Fixed Investment Securities Database) or SDC databases. We primarily employ Moody's bond ratings, and if they are unavailable, we use the Standard \& Poor's ratings whenever possible. This data screening procedure results in 5,559 issues.

\footnotetext{
${ }^{4}$ To ensure that newspaper articles from LexisNexis provide reports on a firm and do not merely mention it in passing, we filter articles that refer to a firm but have a small "relevance score." Following Fang and Peress (2009), our criterion requires a relevance score of greater than or equal to $90 \%$.
} 
We then match the media coverage sample with other firm information. Financial statement information comes from Compustat, stock prices, returns from the Center for Research in Security Prices (CRSP), analyst coverage and earnings forecast dispersions from the Institutional Brokers' Estimate System (IBES) database, corporate governance measures from the database of Institutional Shareholder Services (ISS), board characteristics from BoardEx, and syndicated loan information from the DealScan database. The final matched sample includes 5,338 bonds issued by 741 firms from Jan. 1990 to Jan. 2011. Figure 1 shows the distribution of the number of bonds issued by each firm. The vertical axis denotes the number of firms that issue a certain number of bonds indicated on the horizontal axis. For example, the first bar indicates that 141 firms (or $18 \%$ of the sample) issue only 1 bond over the entire sample period and the right-most bar shows that approximately 20 firms (or $3 \%$ of the firms) issue more than 30 bonds.

FIGURE 1

Distributions of the Number of Bonds Issued

Figure 1 shows the distribution of the number of bond issues by firm. The sample consists of 5,338 bonds issued by 741 firms over the period 1990-2011. The vertical axis represents the number of firms that issue the number of bonds shown on the horizontal axis.

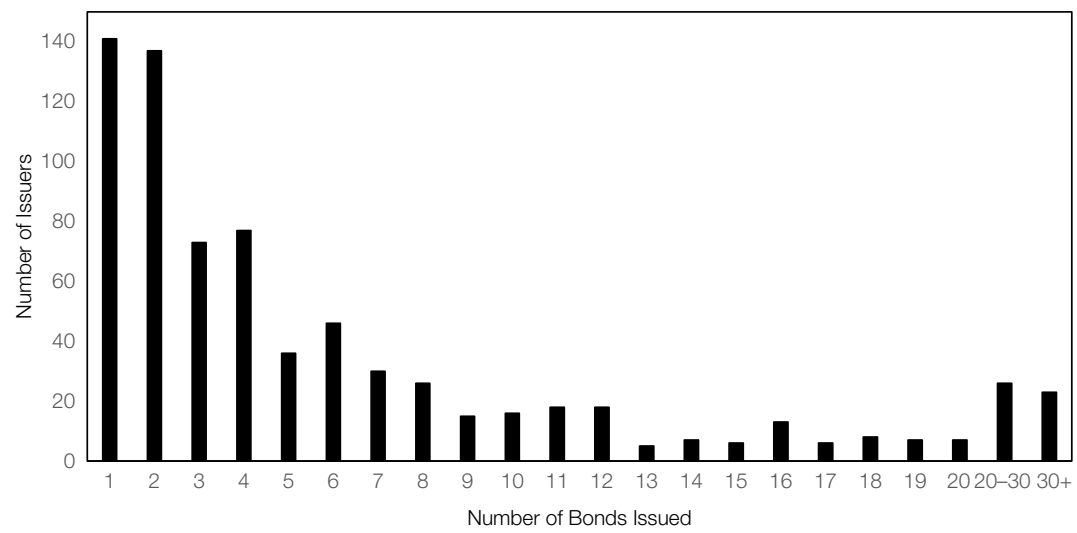

\section{B. Media Coverage Measures and Bond Yield Spreads}

Media coverage, MEDIA, is measured by the total number of newspaper articles written about a firm in the month prior to a bond's offering date. In our empirical investigation, we take the natural logarithm of 1 plus the number of articles, which has been commonly used in prior studies as a proxy for media attention (e.g., Fang and Peress (2009), Liu, Sherman, and Zhang (2014)). We also use two other measures of media coverage. The first is the average of 3-month lagged media coverage, LAG_3M_MEDIA, which is used to capture the potential lagged effects of media coverage. The second coverage measure is the residuals (MEDIA_RES) from the regression of MEDIA against firm/bond characteristic variables that are possible determinants of media coverage. By construction, the residuals are orthogonal to these variables. 
Since bonds have different maturities, offering yields are not directly comparable across bonds. One way to address this issue is to adjust each bond's offering yield by the Treasury yield of equal maturity. However, Treasury bonds typically have smaller coupons and thus a shorter duration relative to the corporate bond of the same maturity. To resolve this problem, we obtain the equivalent risk-free bond yield by constructing a synthetic bond with the same coupon and maturity as the corresponding corporate bond. ${ }^{5}$ The offering yield spread (YIELD_SPREAD) is the corporate bond's offering yield minus the synthetic risk-free bond yield in the offering month.

\section{Control Variables}

We use firm/bond characteristics as control variables in our empirical tests. FIRMSIZE is measured by a firm's total assets and we take its natural log value in our empirical analysis. ${ }^{6}$ LEVERAGE, a measure of financial risk, is defined as total liabilities divided by total assets in book value. We employ firm age to control for the firm's development stage (Anthony and Ramesh (1992)). AGE is measured by the natural log of 1 plus the number of years since the firm's initial offering. The variable EMPLOYEES is the natural $\log$ of 1 plus the number of firm employees (in thousands). To measure the size of the shareholder base (SHAREHOLDERS), we use the number of common/ordinary shareholders in thousands with a similar natural log transformation as EMPLOYEES. To control for operating performance, we employ return-on-asset (ROA), which is defined as the ratio of net income before extraordinary items to total assets (see Core, Guay, and Rusticus (2006)). Following Kogan and Papanikolaou (2014), we use the market-to-book (MTB) ratio at the end of the year prior to the bond offering as a proxy for the firm's future growth opportunities.

To control for the firm's risk and returns, we use stock return volatility (VOLATILITY), measured by the standard deviation and average daily stock returns (RETURN) over the past 250 trading days before the bond offering date (see Campbell and Taksler (2003)). To control for the effect of liquidity (Lin, Wang, and Wu (2011), Bongaerts, de Jong, and Driessen (2017)), we employ both stock and bond liquidity measures. For stock liquidity, we use Amihud's (2002) illiquidity measure, which is daily absolute stock returns divided by daily trading volume. We take the natural log of Amihud's illiquidity measure and multiply it by -1 to convert it into a measure of liquidity (STOCKLIQ), such that a higher value denotes higher liquidity. We calculate the stock liquidity measure over a 1 -year window prior to the bond offering date.

\footnotetext{
${ }^{5}$ To calculate the equivalent risk-free bond yield, we first collect the Treasury spot rates constructed by Gurkaynak, Sack, and Wright (2007) and updated on the Federal Reserve Bank (FRB) Web site. Each month, we discount the coupons and principal of a corporate bond by the spot rates (zero-coupon rates) of Treasury bonds which match the dates of these cash flows. From this, we obtain the synthetic risk-free bond price that has exactly the same coupons and maturity of the corresponding corporate bond. Using this price, coupons, and principal, we back out the yield to maturity for the synthetic risk-free bond and use this equivalent bond yield to obtain the offering yield spreads.

${ }^{6}$ Our results are robust to the use of market value of equity as a measure of firm size.
} 
For bond liquidity (BONDLIQ), we use the price impact measure from Kalimipalli and Nayak (2012) to more effectively gauge corporate bond illiquidity, since bonds trade, less frequently than stocks. Price impact is defined by

$\underline{\text { (max price }-\min \text { price)/average price }}$

total volume

where max price, min price, and average price denote the highest, lowest, and mean transaction prices over the past 1 year, respectively. We average price impacts across all outstanding bonds of the firm which have trades over the 1-year window prior to the bond offering date. Higher price impacts indicate lower liquidity. To be consistent with the stock liquidity measure, we take the natural log value of price impact and multiply it by -1 to measure the issuer's bond liquidity. We also consider the issuer's bond trading volume as an alternative bond liquidity measure and find that our results are robust.

Although our explanatory variables include firm leverage, size, stock return volatility, and credit ratings, we also use two direct measures of default risk: EDF and Z_SCORE. The former is an option-based measure and the latter is an accounting-based measure of default risk. EDF is the expected default frequency estimated from the Merton (1974) model. Following Graham, Li, and Qiu (2008) and Lemmon and Roberts (2010), we use the modified Altman's Z-score (Z_SCORE) as a measure of default risk.

To control for the effects of other information intermediaries, we use several variables. We use analyst coverage and forecast dispersion as proxies for a firm's information environment. Mansi, Maxwell, and Miller (2011) find that these variables are good proxies for both the quantity and quality of information available to investors. We use the natural log of number of analysts (ANALYSTS) as a measure of analyst coverage. DISPERSION is defined by the standard deviation of analyst forecasts for 1-year EPS. To control for underwriter quality, following Fang (2005), we define an indicating variable, REPU_IVBANK, which has a value of 1 if the issuing firm hires a brand name bank (i.e., Goldman Sachs, Merrill Lynch, Morgan Stanley, Salomon Brothers, CSFB, Lehman Brothers, JP Morgan, or DLJ), and 0 otherwise. To control for auditor quality, we define an indicator, BIG_AUDITOR, that has a value of 1 if the firm hires an auditor from the Big 6 group, which shrank to the Big 5 in 1998 and then the Big 4 in 2002, and 0 otherwise. In addition, we use institutional stock ownership from Thomson $13 \mathrm{~F}$ to control for information asymmetry.

GROSS_SPREAD measures the underwriter flotation cost. BOND_PAST 5Y and SEO_PAST_5Y measure the (natural log) size of bond and stock offerings over the past 5 years, through which the firm may have some indirect control over media coverage. We also use the frequency of bond and stock issues in the past 5 years and find that results are robust. The size and reputation of a firm's loan syndicates can convey information. The size of loan syndicates (SYNDICATE_SIZE) is measured by the number of lenders involved in the firm's syndicated loan facility, and reputation (SYNDICATE_REPU) is an indicator that takes a value of 1 if the leading bank ranks among the top 10 in market share over the past 3-year horizon, and 0 otherwise. 
We control for the effects of board characteristics using BOARD_SIZE (the number of directors on the board) and BOARD_IND (the number of independent directors divided by the total number of directors). In addition, we use a broad corporate governance measure, ISS_INDEX, based on the 24 governance standards compiled by the Institutional Shareholder Services (ISS) database. ${ }^{7}$ The ISS index is a broader corporate governance measure than that of Gompers, Ishii, and Metrick (GIM (2003)), which primarily captures antitakeover provisions in a firm's charter, its bylaws, and state law (see Chung, Elder, and Kim (2010)). We control for these governance variables, since they may be related to the level and effectiveness of firm media coverage.

Lastly, we use standard determinants of bond yields, such as credit ratings (RATING), offering proceeds (ISSUE_SIZE), and bond maturity (MATURITY), and a collateral requirement, as additional controls. Following Blume, Lim, and MacKinlay (1998), we convert the ratings from an alphanumerical system to a numerical rating, ranging from zero for AAA bonds to 20 for $\mathrm{C}$ bonds. MATURITY is defined as the years to maturity in natural log value, while ISSUE_SIZE is defined as the total proceeds of a bond issuance in billions and RELATIVE_SIZE is the issue size divided by total asset of the issuer. COLLATERAL is an indicator which takes a value of 1 if a bond has a collateral requirement, and 0 otherwise. Appendix A provides the definition for each variable and sources of the data.

\section{Summary Statistics}

Table 1 reports the yearly distribution of media coverage (MEDIA). Approximately $36 \%$ of the bond issues have no media coverage. The columns under "Noncovered" show the number of bond issues and corresponding issuers that received no news coverage over the 1-month period prior to the bond issuing date. The columns under "Covered" report the number of corporate bonds and issuers covered by at least 1 newspaper article in the month prior to bond issuance. For these issuers, the average number of newspaper articles is approximately 10 over the sample period. ${ }^{8}$ Figure 2 displays the proportion of bond issues (the vertical axis) that received media coverage in each calendar year (the horizontal axis). As shown, the majority of bond issues in the sample are covered by the media.

Table 2 provides a summary of variables. Panel A shows descriptive statistics for the main variables used in regressions. The average offering yield spread is $1.88 \%$. Panel B reports the distribution of offering yields and yield spreads for 4 rating categories: AAA/AA, A, BBB, and junk bonds with different maturities. Offering yield spreads increase as the rating decreases, averaging $0.71 \%$ for AAA/AA bonds and $3.12 \%$ for junk bonds.

Unreported results show a significant negative correlation between media coverage and offering yield spreads, suggesting that media attention is inversely correlated with the cost of debt. Consistent with previous findings, offering yield spreads are negatively correlated with firm size (see Bhojraj and Sengupta (2003), Anderson et al. (2004)), firm age (Pittman and Fortin (2004)), analyst following

\footnotetext{
${ }^{7}$ The ISS index is constructed based on 24 governance standards in 6 categories that are most closely related to financial and operational transparency.

${ }^{8}$ The distribution is skewed with a median of 4 and standard deviation of 14.63 .
} 
TABLE 1

\section{Distribution of Media Coverage}

Table 1 reports the summary statistics for bond issues, issuers, and media coverage by year over the sample period 1990-2011. The sample consists of 5,338 observations after merging the SDC and media coverage data sets. The column "Noncovered" lists the total number of bond issues and issuers receiving no media coverage in the month prior to the bond issuance date, and "Covered" refers to the firms with at least 1 news article provided by business media. For the covered firms, the mean, standard deviation, median, and the first and third quartiles (P25 and P75) of the number of newspaper articles are reported.

\begin{tabular}{|c|c|c|c|c|c|c|c|c|c|c|c|}
\hline \multirow[b]{3}{*}{ Year } & & & & & \multicolumn{7}{|c|}{ Covered } \\
\hline & \multicolumn{2}{|c|}{ Overall } & \multicolumn{2}{|c|}{ Noncovered } & \multicolumn{2}{|c|}{ Number } & \multicolumn{5}{|c|}{ No. of Newspaper Articles } \\
\hline & Issues & Issuer & Issues & Issuers & Issues & Issuers & Mean & Std. Dev. & P25 & Median & P75 \\
\hline 1990 & 52 & 31 & 6 & 6 & 46 & 27 & 19.48 & 28.08 & 4.00 & 8.00 & 14.00 \\
\hline 1991 & 146 & 67 & 15 & 14 & 131 & 55 & 23.08 & 26.23 & 4.00 & 14.00 & 30.00 \\
\hline 1992 & 149 & 67 & 8 & 6 & 141 & 63 & 14.70 & 18.62 & 4.00 & 7.00 & 17.00 \\
\hline 1993 & 164 & 89 & 27 & 25 & 137 & 67 & 13.01 & 17.69 & 3.00 & 7.00 & 15.00 \\
\hline 1994 & 95 & 48 & 17 & 14 & 78 & 35 & 10.44 & 9.61 & 3.00 & 8.00 & 13.00 \\
\hline 1995 & 135 & 76 & 23 & 19 & 112 & 61 & 10.04 & 14.81 & 2.00 & 5.00 & 10.00 \\
\hline 1996 & 187 & 84 & 41 & 30 & 146 & 58 & 14.67 & 20.28 & 3.00 & 8.00 & 18.00 \\
\hline 1997 & 256 & 125 & 67 & 50 & 189 & 82 & 9.15 & 13.29 & 2.00 & 4.00 & 10.00 \\
\hline 1998 & 375 & 159 & 83 & 58 & 292 & 110 & 8.72 & 14.78 & 2.00 & 3.00 & 8.00 \\
\hline 1999 & 280 & 138 & 79 & 57 & 201 & 84 & 9.42 & 11.99 & 2.00 & 3.00 & 15.00 \\
\hline 2000 & 179 & 86 & 78 & 47 & 101 & 49 & 7.36 & 9.08 & 2.00 & 4.00 & 10.00 \\
\hline 2001 & 403 & 198 & 150 & 102 & 253 & 107 & 7.16 & 11.30 & 1.00 & 3.00 & 5.00 \\
\hline 2002 & 360 & 172 & 104 & 76 & 256 & 106 & 9.91 & 12.88 & 2.00 & 5.00 & 12.00 \\
\hline 2003 & 324 & 201 & 153 & 107 & 171 & 106 & 10.18 & 17.03 & 1.00 & 3.00 & 11.00 \\
\hline 2004 & 236 & 151 & 135 & 97 & 101 & 59 & 6.70 & 7.77 & 1.00 & 3.00 & 10.00 \\
\hline 2005 & 222 & 144 & 122 & 83 & 100 & 65 & 7.01 & 10.78 & 1.00 & 2.00 & 8.00 \\
\hline 2006 & 244 & 146 & 107 & 75 & 137 & 73 & 8.58 & 13.90 & 1.00 & 3.00 & 7.00 \\
\hline 2007 & 321 & 169 & 145 & 93 & 176 & 78 & 7.10 & 9.49 & 2.00 & 4.00 & 8.00 \\
\hline 2008 & 267 & 129 & 94 & 63 & 173 & 72 & 7.40 & 8.35 & 2.00 & 4.00 & 9.00 \\
\hline 2009 & 462 & 241 & 213 & 142 & 249 & 113 & 8.12 & 9.13 & 2.00 & 5.00 & 11.00 \\
\hline 2010 & 458 & 264 & 238 & 168 & 220 & 106 & 8.30 & 11.59 & 1.00 & 3.00 & 10.00 \\
\hline 2011 & 23 & 19 & 19 & 15 & 4 & 4 & 3.25 & 2.22 & 2.00 & 3.00 & 5.00 \\
\hline Total & 5,338 & 741 & 1,924 & 582 & 3,414 & 444 & 9.90 & 14.63 & 2.00 & 4.00 & 11.00 \\
\hline
\end{tabular}

\section{FIGURE 2}

\section{Temporal Distributions of the Frequency of Bond Issues with Media Coverage}

Figure 2 shows the time trend of the proportion of issues with media coverage in the month prior to the offering day. The vertical axis represents the proportion of bond issues that have media coverage and the year is indicated on the horizontal axis.

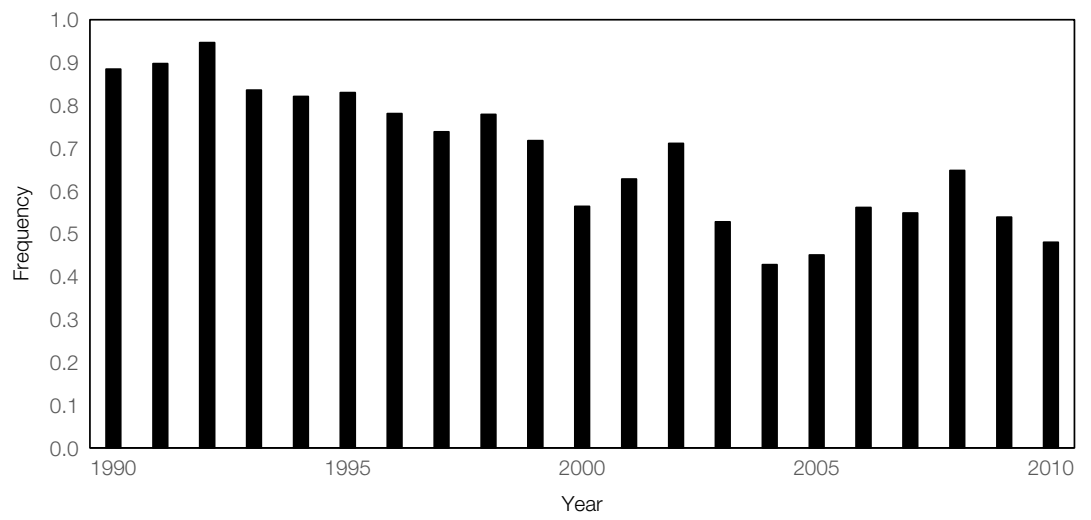

(Mansi et al. (2011)), and are positively correlated with leverage (Borisova and Megginson (2011)), analyst forecast dispersion (Mansi et al. (2011)), and equity return volatility (Campbell and Taksler (2003)). Larger and older firms, and firms 
TABLE 2

Summary Statistics

Table 2 reports the descriptive statistics of the main variables used in the regressions. The sample period runs from 1990 to 2011. Panel A shows the summary statistics of the variables. All variables are defined in Appendix A. Panel B presents the descriptive statistics of offering yields and yield spreads for 4 ratings and 3 maturity groups. The $t$-values are reported in the parentheses. * ${ }^{* *}$, and ${ }^{* * *}$ indicate the significance at the $10 \%, 5 \%$, and $1 \%$ levels, respectively.

Panel A. Descriptive Statistics

\begin{tabular}{|c|c|c|c|c|c|}
\hline Variables & Mean & Median & Std. Dev. & P25 & P75 \\
\hline YIELD_SPREAD & 1.88 & 1.43 & 1.49 & 0.77 & 2.98 \\
\hline MEDIA & 6.33 & 2.00 & 12.63 & 0.00 & 6.00 \\
\hline RATING & 7.74 & 7.00 & 3.95 & 5.00 & 10.00 \\
\hline MATURITY & 10.78 & 10.00 & 7.51 & 5.50 & 10.08 \\
\hline ISSUE_SIZE & 543.42 & 300.00 & 553.19 & 165.00 & 750.00 \\
\hline COLLATERAL & 0.17 & 0.00 & 0.37 & 0.00 & 0.00 \\
\hline FIRMSIZE & 15.58 & 6.44 & 21.35 & 2.16 & 20.10 \\
\hline LEVERAGE & 0.63 & 0.62 & 0.14 & 0.53 & 0.73 \\
\hline AGE & 34.10 & 31.00 & 23.79 & 13.00 & 52.00 \\
\hline EMPLOYEES & 75.67 & 30.34 & 131.10 & 11.20 & 66.00 \\
\hline ROA & 0.05 & 0.05 & 0.05 & 0.02 & 0.08 \\
\hline SHAREHOLDERS & 89.91 & 18.24 & 170.90 & 3.63 & 60.98 \\
\hline ANALYSTS & 19.80 & 19.00 & 10.04 & 12.00 & 27.00 \\
\hline DISPERSION & 0.23 & 0.12 & 0.28 & 0.05 & 0.28 \\
\hline MTB & 1.69 & 1.51 & 0.62 & 1.19 & 2.13 \\
\hline RETURN & 0.07 & 0.06 & 0.12 & -0.02 & 0.14 \\
\hline VOLATILITY & 2.30 & 2.06 & 0.97 & 1.55 & 2.76 \\
\hline STOCK_LIQ & 11.05 & 11.12 & 1.71 & 9.96 & 12.24 \\
\hline BOND_LIQ & 1.97 & 1.98 & 0.99 & 1.39 & 2.61 \\
\hline SEO_PAST_5Y & 0.13 & 0.00 & 0.34 & 0.00 & 0.00 \\
\hline BOND_PAST_5Y & 1.57 & 0.00 & 2.37 & 0.00 & 2.00 \\
\hline REPU_IVBANK & 0.75 & 0.00 & 0.43 & 0.00 & 1.00 \\
\hline BIG_AUDITOR & 0.79 & 1.00 & 0.48 & 0.00 & 1.00 \\
\hline INST̄ITUTIONAL & 0.69 & 0.71 & 0.19 & 0.57 & 0.83 \\
\hline SYNDICATE_SIZE & 6.29 & 1.00 & 8.85 & 0.00 & 11.00 \\
\hline SYNDICATE_REPU & 0.24 & 0.00 & 0.43 & 0.00 & 0.00 \\
\hline Z_SCORE & 1.58 & 1.57 & 0.98 & 0.99 & 2.20 \\
\hline EDF & 0.10 & 0.00 & 0.22 & 0.00 & 0.06 \\
\hline BOARD_SIZE & 8.91 & 9.00 & 2.93 & 8.00 & 11.00 \\
\hline BOARD_IND & 0.58 & 0.63 & 0.26 & 0.43 & 0.78 \\
\hline ISS_INDEXX & 12.54 & 13.00 & 2.74 & 11.00 & 15.00 \\
\hline
\end{tabular}

Panel B. Yields by Rating and Maturity

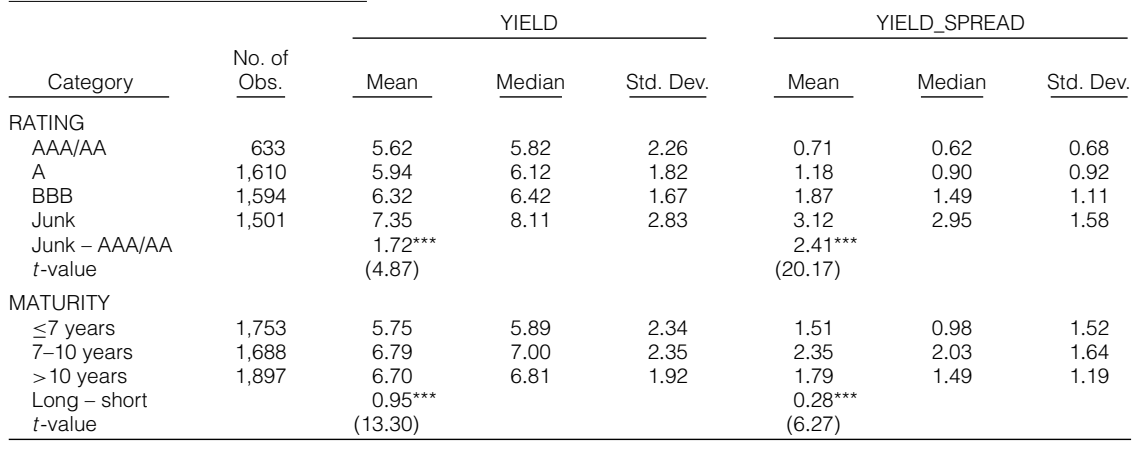

with a larger number of shareholders, higher credit ratings, and lower volatility have more media coverage (Fang and Peress (2009), Liu et al. (2014)). Underwriter and auditor reputation, the size and reputation of loan syndicates, the governance indices, board independence, and institutional share ownership are negatively correlated with media coverage. Overall, correlations among key explanatory variables of yield spreads and media coverage are moderate. The variance inflation factor (VIF) tests suggest that multicollinearity is not a serious concern. 


\section{Determinants of Media Coverage}

We begin our analysis by examining what drives the cross-sectional variation in media coverage across bond issuers. Understanding this issue is important as it helps explain why some bond issuers receive more media coverage than others. The literature has suggested that media coverage is correlated with firm characteristics. Firms with larger equity capitalization, a larger analyst following, more employees and shareholders, better ratings, and higher growth (MTB) tend to attract more media coverage. Media coverage is also likely to display a positive correlation with stock and bond liquidity (see Blankespoor et al. (2014)) and the size of past stock and bond issues, and a negative correlation with firm risk. Firms hiring underwriters and auditors with a better reputation may have less media coverage, possibly because access to these agents reduces the need for media coverage. A larger size and better reputation of a firm's loan syndicates could also reduce the need for media coverage. Moreover, higher institutional ownership may substitute for media monitoring, whereas firms with poor governance can at times attract more media coverage.

To ascertain the determinants of the level of media coverage, we run the panel regression of the number of newspaper articles (in natural log value) on firm characteristics. For board quality, we mainly use the measures of board independence and size (see also Anderson et al. (2004)). To capture general corporate governance quality, we use the governance index (ISS_INDEX) constructed from the 24 ISS governance standards. ${ }^{9}$ For underwriter and auditor quality, we use the indicators of highly ranked investment banks and auditors (see Fang (2005)). In addition, we include the size of syndicate loans and the reputation of the firm's lead syndicate banks in the regressions. We also account for year and industry fixed effects of (Fama-French 48 industry classifications) and calculate the $t$-values based on the standard errors clustered at the issuer level.

Table 3 reports the results of panel regressions with $t$-values in parentheses. Model 1 includes conventional firm characteristics. Results show that media coverage is positively related to firm size, number of employees, market-to-book ratio, number of analysts following the firm, and forecast dispersion, and negatively related to the rating indicator (high value indicating low quality). These results suggest that the media are more likely to follow large, mature, influential, and better rated firms. This is consistent with the findings of Deephouse (2000) and Ailawadi, Lehmann, and Neslin (2003), who report that these firms have a greater influence and better access to the media. The positive sign of earnings forecast dispersion is in line with the finding of Fang and Peress (2009).

Model 2 of Table 3 adds stock and bond characteristics, such as past stock returns, volatility and liquidity, number of shareholders, total stock and bond offerings over the past 5 years, and the default risk measures EDF and Z_SCORE.

\footnotetext{
${ }^{9}$ We also use other board and governance quality measures and our results are robust. For example, we use several other measures for board independence (i.e., CEO chair duality, co-opted board, the fraction of the board comprised of directors appointed after the CEO assumed office) and other measures of board quality (i.e., CEO's industry experience and connections of board members). We also consider governance scores based on the minimum standards in ISS Corporate Governance: Best Practices User Guide and Glossary, and 36 governance standards similar to Chung and Zhang (2011). We could not use all of these variables in regressions due to their high correlation.
} 


\section{TABLE 3}

\section{Determinants of Media Coverage}

Table 3 reports the regressions of media coverage on the determinants of media coverage. The sample consists of 5,338 observations, over the period 1990-2011. The dependent variable is measured by the natural logarithm of 1 plus the total number of newspaper articles in the month prior to the bond issuance date. All variables are defined in Appendix A. The constants are omitted for brevity. Year and Fama-French (FF) 48 industry fixed effects are included in all regressions. The $t$-values based on standard errors clustered at issuer level are reported in parentheses. ${ }^{*}$, ${ }^{*}$, and ${ }^{* * *}$ indicate the significance at the $10 \%, 5 \%$, and $1 \%$ levels, respectively.

\begin{tabular}{lc} 
& 1 \\
\cline { 2 - 2 } RATING & $-0.031^{* *}$ \\
FIRM_SIZE & $(-2.52)$ \\
& $0.343^{* * *}$ \\
EMPLOYEES & $(4.40)$ \\
& $0.096^{* \star \star}$ \\
MTB & $(3.05)$ \\
& 0.046 \\
ANALYSTS & $(1.03)$ \\
& $0.190^{* *}$ \\
DISPERSION & $(2.24)$ \\
& $0.450^{* * *}$ \\
& $(3.02)$
\end{tabular}

\begin{tabular}{c}
2 \\
\hline-0.003 \\
$(-0.27)$ \\
$0.384^{\star \star \star}$ \\
$(5.14)$ \\
$0.060^{\star}$ \\
$(1.74)$ \\
$0.097^{\star \star}$ \\
$(2.54)$ \\
0.091 \\
$(1.41)$ \\
$0.246^{\star *}$ \\
$(2.37)$ \\
$0.108^{\star \star \star}$ \\
$(4.98)$ \\
0.170 \\
$(1.08)$ \\
0.025 \\
$(0.90)$ \\
-0.038 \\
$(-0.68)$ \\
0.002 \\
$(0.14)$ \\
$-0.035^{\star}$ \\
$(-1.67)$ \\
-0.107 \\
$(-0.88)$ \\
0.023 \\
$(0.52)$ \\
-0.026 \\
$(-0.32)$ \\
$0.139^{\star \star *}$ \\
$(2.93)$ \\
\\
\end{tabular}

\begin{tabular}{c}
3 \\
\hline-0.002 \\
$(-0.18)$ \\
$0.381^{\star \star \star}$ \\
$(5.06)$ \\
0.054 \\
$(1.56)$ \\
$0.075^{\star}$ \\
$(1.88)$ \\
0.106 \\
$(1.64)$ \\
$0.265^{\star \star}$ \\
$(2.53)$ \\
$0.104^{\star \star \star}$ \\
$(4.85)$ \\
0.225 \\
$(1.39)$ \\
0.025 \\
$(0.93)$
\end{tabular}

\begin{tabular}{|c|}
\hline 4 \\
\hline $\begin{array}{l}-0.007 \\
(-0.62)\end{array}$ \\
\hline $\begin{array}{l}0.311^{* * *} \\
(4.71)\end{array}$ \\
\hline $\begin{array}{c}0.059 \\
(1.49)\end{array}$ \\
\hline $\begin{array}{c}0.055 \\
(1.38)\end{array}$ \\
\hline $\begin{array}{c}0.056 \\
(0.95)\end{array}$ \\
\hline $\begin{array}{l}0.311^{* * *} \\
(2.80)\end{array}$ \\
\hline
\end{tabular}

SHAREHOLDERS

RETURN

VOLATILITY

$-0.026$

STOCK_LIQ

$(-0.44)$

0.006

(0.36)

$-0.031$

BOND_LIQ

Z_SCORE

EDF

SEO_PAST_5Y

BOND_PAST_5Y

SYNDICATE_SIZE

SYNDICATE_REPU

$(-1.49)$

$-0.137$

$(-1.14)$

0.044

(1.08)

$0.115^{\text {** }}$

(4.86)

$0.380^{\text {** }}$

(2.12)

0.016

(0.50)

0.057

(1.62)

0.009

(0.52)

$-0.032$

$(-1.40)$

$-0.054$

$(-0.41)$

0.008

(0.17)

$-0.021$

$(-0.26)$

0.008

$(0.09)$

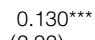

$0.123^{\text {*** }}$

(2.70)

$-0.021^{*}$

$(-1.95)$

$-0.025^{*}$

0.039

$(-2.02)$

(0.95)

0.036

$-0.247^{*}$

$(-1.67)$

$-0.023$

$(-0.80)$

(0.81)

INSTITUTIONAL

REPU_IVBANK

$-0.108^{*}$

$(-1.76)$

$-0.354^{* *}$

$(-2.21)$

$-0.024$

$(-0.80)$

BIG_AUDITOR

BOARD_SIZE

$(-1.59)$

$-0.042$

(-0.51)

$-0.039$

$(-0.36)$

$-0.161^{\text {** }}$

$(-2.44)$

ISS_INDEX

FF 48-industry fixed effects

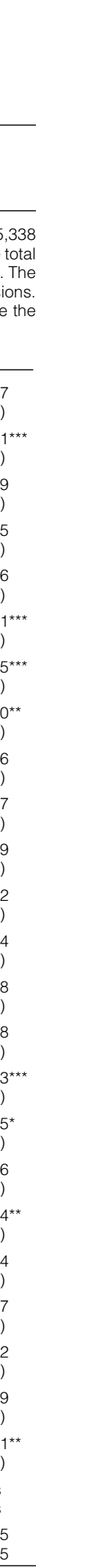


Media coverage is positively related to the number of shareholders and the size of past bond offerings, and negatively related to bond and stock liquidity. ${ }^{10}$ Model 3 adds controls for reputable investment banks and auditors, the size and reputation of a firm's loan syndicates, and the proportion of outstanding shares held by institutional investors. The negative coefficient of institutional ownership suggests that firms with lower institutional ownership are more likely to receive media attention. The coefficients of reputable investment banks and auditors, and the size of loan syndicates are also negative, implying that better underwriter and auditor quality and larger syndicate size reduce the need for media coverage.

Model 4 of Table 3 further includes measures of board quality and corporate governance. Board independence and the governance index (ISS_INDEX) are negatively related to the level of media coverage, suggesting that firms with poor governance and board quality attract more media coverage. The governance index remains significant $(t=-2.44)$ even after controlling for the effect of bond/firm characteristics and other firm attributes. The regression model explains a high proportion of the cross-sectional variation in media coverage with an adjusted $R^{2}$ of $69 \%$.

\section{Relations between Media Coverage and Offering Yield Spreads}

We next examine the relation between media coverage and a firm's cost of borrowing in the corporate bond market. We first show that media coverage has a significantly negative association with bond offering yield spreads, and that this association is robust to different controls for the effects of information asymmetry, corporate governance, liquidity, credit risk, and other characteristics. We then conduct multiple tests to address potential endogeneity concerns and investigate the channels through which media coverage influences the cost of debt. Finally, we examine whether media coverage also influences the underwriting cost of public debt.

\section{A. Univariate Portfolio Analysis}

To provide direct and intuitive evidence on the hypothesized media coverage impact, we analyze the relation between media coverage and offering yield spreads using portfolio sorts. We first divide the sample based on whether there is news coverage in the month prior to the bond issuance, and then sort the subsample for the bonds of firms with coverage into quartiles based on the total number of news articles.

Panel A of Table 4 reports the results of portfolio sorts, including the mean, median, and standard deviation for each group. The first column shows the results for bonds with no media coverage, and the next four columns for bonds with increasing levels of coverage. Results show a clear pattern of a monotonically decreasing relation between offering yield spreads and media coverage from the group with no coverage $(\mathrm{N})$ to that with the most extensive media coverage $(\mathrm{H})$.

\footnotetext{
${ }^{10}$ Using the frequency of past offerings generates a similar positive relation with media coverage.
} 
TABLE 4 Table 4 reports the results of our portfolio and regression analysis. Panel A reports univariate portfolio analyses of average bond yield spreads. The first column reports the summary statistics of yield spreads for differences in yield spreads between no-coverage and high-coverage portfolios $(\mathrm{N}-\mathrm{H})$ and between low- and high-coverage portfolios $(\mathrm{L}-\mathrm{H})$. Panel B reports the regressions of yield spreads on media coverage and other variables. MEDIA is the main explanatory variable, defined as the natural logarithm of 1 plus the number of newspaper articles during the month prior to bond issuing. Column 1 reports the regression results where explanatory variables include firm/bond characteristics, and other controls consisting of term structure and capital structure variables. Columns $2-9$ add CONTROL_X, which includes variables related to information asymmetry, corporate governance, liquidity, and default risk, respectively. Column 10 includes all of these channel variables. Control variables include RATING. MATURITY, ISSUESIZE, LEVERAGE, AGE, ROA and COLLATERAL. The constant and the coefficients of control variables are omitted for brevity. Year and Fama-French (FF) 48 industry fixed effects are included in all regressions, and $t$-values based on standard errors clustered at the issuer level are reported in parentheses. All variables used are defined in Appendix A. ${ }^{*}$, ${ }^{\star *}$, and ${ }^{* * *}$ indicate the significance at the $10 \%, 5 \%$, and $1 \%$ levels, respectively.

Panel A. Univariate Portfolio Sorts

\begin{tabular}{|c|c|c|c|c|}
\hline & Non-Covered & Low & 2 & 3 \\
\hline No. of obs. & 1,924 & 1,177 & 565 & 843 \\
\hline Mean & 2.49 & 1.91 & 1.50 & 1.40 \\
\hline Median & 2.29 & 1.42 & 1.18 & 1.00 \\
\hline Std. Dev. & 1.60 & 1.42 & 1.19 & 1.26 \\
\hline
\end{tabular}

High
829
1.16
0.89
1.11

$\underline{\mathrm{N}-\mathrm{H}}$

$1.33^{\star \star \star}$

$\underline{\text { Panel B. Regression Results }}$

Basic

Controls

MEDIA

$$
\frac{1}{-0.144^{\text {** }}}
$$

CONTROL_X

RETURN

VOLATILITY$$
\begin{aligned}
& -1.310^{\text {** }} \\
& (-6.49)
\end{aligned}
$$$$
0.350^{* \star \star}
$$$$
\text { (7.95) }
$$

FIRMSIZE

$$
\begin{aligned}
& -0.086^{*} \\
& (-1.90)
\end{aligned}
$$

\section{Corporate Governance}

BOARD IND

$\frac{4}{-0.146^{\star \star \star}}$

$(-3.96)$

$-0.200^{*}$

$(-1.74)$

$-1.314^{\star \star \star}$

$(-5.85)$

$0.368^{\text {*** }}$

(7.30)

$-0.029$

-0.029
$(-0.58)$

$$
\begin{gathered}
\text { REPU_IVBANK } \\
3 \\
\hline-0.145^{\star \star \star} \\
(-4.26) \\
-0.347^{\star \star \star} \\
(-8.10) \\
-1.288^{\star \star \star} \\
(-6.49) \\
0.347^{\star \star \star} \\
(7.99) \\
-0.075^{\star} \\
(-1.65)
\end{gathered}
$$

ISS INDEX

$\frac{5}{-0.146^{* * *}}$

$(-3.98)$

$-0.050^{*}$

$(-1.93)$

$-1.320^{\star \star \star}$

$(-5.87)$

$0.368^{* * *}$

(7.29)

-0.031
$(-0.62)$
Liquidity

\section{BOND_LIQ}

6

$(-4.12)$

$-0.094^{* *}$

$(-3.99)$

$-1.422^{\text {** }}$

$(-6.63)$

$0.330^{\star \star \star *}$

(7.52)

$-0.099^{\text {** }}$

$(-2.18)$ $\underline{t \text {-Value }}$

(21.75)

L-H

$0.71^{\star \star \star}$

$\underline{t \text {-Value }}$

(12.74)

STOCK_LIQ
$\frac{7}{-0.157^{\star \star \star}}$
$(-4.35)$
$-0.108^{\star \star \star}$
$(-2.81)$
$-1.238^{\star \star \star}$
$(-5.81)$
$0.356^{\star \star \star}$
$(7.54)$
0.015
$(0.25)$

Include All

4 Key

Variables

\section{Z_SCORE}

8

$-0.144^{\star}$
$(-4.27)$

$-0.053^{*}$

$(-1.72)$

$-1.321^{\text {** }}$

$(-6.55)$

$0.350^{\text {*** }}$

(7.94)

$-0.099^{\star \star *}$

$(-2.08)$

\begin{tabular}{c} 
EDF \\
9 \\
\hline$-0.138^{\star \star \star}$ \\
$(-3.91)$ \\
$0.289^{\star}$ \\
$(1.69)$ \\
$-1.163^{\star \star \star}$ \\
$(-5.39)$ \\
$0.342^{\star \star \star}$ \\
$(7.41)$ \\
-0.073 \\
$(-1.54)$
\end{tabular}

$-0.146^{\text {** }}$

$(-3.71)$

YES

$-1.157^{\star \star \star}$

$(-4.34)$

$0.315^{\text {** }}$

(5.75)

-0.073
$(-1.54)$

$0.128^{*}$

(1.90)

(continued on next page) 
TABLE 4 (continued)

Offering Yield Spreads of the Media Coverage Effect

\begin{tabular}{|c|c|c|c|c|c|c|c|c|c|c|}
\hline & \multirow[b]{2}{*}{$\begin{array}{l}\text { Basic } \\
\text { Controls }\end{array}$} & \multicolumn{2}{|c|}{ Information Asymmetry } & \multicolumn{2}{|c|}{ Corporate Governance } & \multicolumn{2}{|c|}{ Liquidity } & \multicolumn{2}{|c|}{ Default Risk } & \multirow{3}{*}{$\begin{array}{c}\text { Include All } \\
4 \text { Key } \\
\text { Variables } \\
10 \\
\end{array}$} \\
\hline & & ANALYSTS & REPU_IVBANK & BOARD_IND & ISS_INDEX & BOND_LIQ & STOCK_LIQ & Z_SCORE & EDF & \\
\hline & 1 & 2 & 3 & 4 & 5 & 6 & 7 & 8 & 9 & \\
\hline MTB & $\begin{array}{l}-0.107^{\star \star} \\
(-2.16)\end{array}$ & $\begin{array}{c}-0.079 \\
(-1.56)\end{array}$ & $\begin{array}{l}-0.087^{\star} \\
(-1.78)\end{array}$ & $\begin{array}{l}-0.146^{\star \star \star} \\
(-2.68)\end{array}$ & $\begin{array}{l}-0.146^{\star \star \star} \\
(-2.66)\end{array}$ & $\begin{array}{l}-0.126^{\star \star} \\
(-2.55)\end{array}$ & $\begin{array}{l}-0.033 \\
(-0.63)\end{array}$ & $\begin{array}{l}-0.112^{\star \star} \\
(-2.26)\end{array}$ & $\begin{array}{l}-0.121^{\star \star} \\
(-2.46)\end{array}$ & $\begin{array}{l}-0.001 \\
(-0.02)\end{array}$ \\
\hline SHAREHOLDERS & $\begin{array}{l}0.041^{\star \star} \\
(2.07)\end{array}$ & $\begin{array}{l}0.040^{\star \star} \\
(2.02)\end{array}$ & $\begin{array}{l}0.042^{\star \star} \\
(2.14)\end{array}$ & $\begin{array}{l}0.048^{\star \star} \\
(2.32)\end{array}$ & $\begin{array}{l}0.048^{\star \star} \\
(2.33)\end{array}$ & $\begin{array}{l}0.043^{\star \star} \\
(2.14)\end{array}$ & $\begin{array}{l}0.050^{\star \star} \\
(2.38)\end{array}$ & $\begin{array}{l}0.041^{\star \star} \\
(2.10)\end{array}$ & $\begin{array}{l}0.045^{\star \star} \\
(2.20)\end{array}$ & $\begin{array}{l}0.070^{\star \star \star} \\
(2.95)\end{array}$ \\
\hline EMPLOYEES & $\begin{array}{c}0.052 \\
(1.46)\end{array}$ & $\begin{array}{c}0.049 \\
(1.39)\end{array}$ & $\begin{array}{c}0.055 \\
(1.57)\end{array}$ & $\begin{array}{c}0.001 \\
(0.01)\end{array}$ & $\begin{array}{c}0.000 \\
(0.01)\end{array}$ & $\begin{array}{c}0.059 \\
(1.64)\end{array}$ & $\begin{array}{l}0.069^{*} \\
(1.87)\end{array}$ & $\begin{array}{l}0.062^{*} \\
(1.72)\end{array}$ & $\begin{array}{c}0.060 \\
(1.64)\end{array}$ & $\begin{array}{c}0.052 \\
(1.16)\end{array}$ \\
\hline DISPERSION & $\begin{array}{c}0.121 \\
(0.88)\end{array}$ & $\begin{array}{c}0.125 \\
(0.90)\end{array}$ & $\begin{array}{c}0.138 \\
(0.97)\end{array}$ & $\begin{array}{c}0.144 \\
(1.04)\end{array}$ & $\begin{array}{c}0.145 \\
(1.04)\end{array}$ & $\begin{array}{l}-0.023 \\
(-0.19)\end{array}$ & $\begin{array}{c}0.136 \\
(0.82)\end{array}$ & $\begin{array}{c}0.120 \\
(0.88)\end{array}$ & $\begin{array}{l}-0.017 \\
(-0.15)\end{array}$ & $\begin{array}{l}-0.112 \\
(-0.72)\end{array}$ \\
\hline SEO_PAST_5Y & $\begin{array}{l}0.093 \\
(1.06)\end{array}$ & $\begin{array}{l}0.110 \\
(1.24)\end{array}$ & $\begin{array}{c}0.084 \\
(0.96)\end{array}$ & $\begin{array}{l}0.157^{*} \\
(1.68)\end{array}$ & $\begin{array}{l}0.158^{*} \\
(1.69)\end{array}$ & $\begin{array}{c}0.086 \\
(1.00)\end{array}$ & $\begin{array}{l}0.194^{\star \star} \\
(2.06)\end{array}$ & $\begin{array}{l}0.100 \\
(1.14)\end{array}$ & $\begin{array}{c}0.112 \\
(1.27)\end{array}$ & $\begin{array}{l}0.292^{\star \star \star} \\
(2.91)\end{array}$ \\
\hline BOND_PAST_5Y & $\begin{array}{l}-0.014 \\
(-0.36)\end{array}$ & $\begin{array}{l}-0.014 \\
(-0.35)\end{array}$ & $\begin{array}{l}-0.013 \\
(-0.33)\end{array}$ & $\begin{array}{c}-0.048 \\
(-1.25)\end{array}$ & $\begin{array}{c}-0.048 \\
(-1.24)\end{array}$ & $\begin{array}{l}-0.035 \\
(-0.89)\end{array}$ & $\begin{array}{l}-0.012 \\
(-0.29)\end{array}$ & $\begin{array}{c}-0.019 \\
(-0.49)\end{array}$ & $\begin{array}{l}-0.047 \\
(-1.29)\end{array}$ & $\begin{array}{l}-0.071^{*} \\
(-1.72)\end{array}$ \\
\hline BIGAUDITOR & $\begin{array}{c}0.005 \\
(0.07)\end{array}$ & $\begin{array}{l}0.003 \\
(0.05)\end{array}$ & $\begin{array}{l}0.008 \\
(0.13)\end{array}$ & $\begin{array}{c}0.026 \\
(0.38)\end{array}$ & $\begin{array}{c}0.030 \\
(0.45)\end{array}$ & $\begin{array}{c}0.035 \\
(0.54)\end{array}$ & $\begin{array}{c}-0.022 \\
(-0.31)\end{array}$ & $\begin{array}{c}0.023 \\
(0.36)\end{array}$ & $\begin{array}{c}0.004 \\
(0.05)\end{array}$ & $\begin{array}{c}0.009 \\
(0.13)\end{array}$ \\
\hline INSTITUTIONAL & $\begin{array}{l}-0.313^{\star \star} \\
(-2.33)\end{array}$ & $\begin{array}{l}-0.260^{\star} \\
(-1.93)\end{array}$ & $\begin{array}{l}-0.324^{\star *} \\
(-2.42)\end{array}$ & $\begin{array}{l}-0.167 \\
(-1.09)\end{array}$ & $\begin{array}{r}-0.112 \\
(-0.68)\end{array}$ & $\begin{array}{l}-0.307^{\text {** }} \\
(-2.27)\end{array}$ & $\begin{array}{l}-0.344^{\star \star} \\
(-2.38)\end{array}$ & $\begin{array}{l}-0.312^{\star \star} \\
(-2.33)\end{array}$ & $\begin{array}{l}-0.342^{\star \star} \\
(-2.51)\end{array}$ & $\begin{array}{l}-0.046 \\
(-0.23)\end{array}$ \\
\hline SYNDICATE_SIZE & $\begin{array}{l}0.123^{*} \\
(1.95)\end{array}$ & $\begin{array}{l}0.117^{\star} \\
(1.86)\end{array}$ & $\begin{array}{l}0.140^{\star *} \\
(2.18)\end{array}$ & $\begin{array}{l}-0.114 \\
(-1.26)\end{array}$ & $\begin{array}{c}0.034 \\
(0.26)\end{array}$ & $\begin{array}{l}0.161^{\star *} \\
(2.49)\end{array}$ & $\begin{array}{r}0.107 \\
(1.58)\end{array}$ & $\begin{array}{l}0.125^{\star \star} \\
(2.00)\end{array}$ & $\begin{array}{l}0.150^{\star \star} \\
(2.46)\end{array}$ & $\begin{array}{l}-0.067 \\
(-0.22)\end{array}$ \\
\hline SYNDICATE_REPU & $\begin{array}{c}0.019 \\
(1.00)\end{array}$ & $\begin{array}{c}0.018 \\
(0.96)\end{array}$ & $\begin{array}{c}0.023 \\
(1.22)\end{array}$ & $\begin{array}{c}0.006 \\
(0.32)\end{array}$ & $\begin{array}{c}0.006 \\
(0.31)\end{array}$ & $\begin{array}{c}0.028 \\
(1.40)\end{array}$ & $\begin{array}{c}0.022 \\
(1.10)\end{array}$ & $\begin{array}{c}0.020 \\
(1.07)\end{array}$ & $\begin{array}{c}0.028 \\
(1.48)\end{array}$ & $\begin{array}{c}0.021 \\
(0.95)\end{array}$ \\
\hline BOARD_SIZE & $\begin{array}{l}-0.143^{\star \star} \\
(-2.55)\end{array}$ & $\begin{array}{l}-0.141^{\star \star} \\
(-2.53)\end{array}$ & $\begin{array}{l}-0.153^{\star \star \star} \\
(-2.76)\end{array}$ & $\begin{array}{l}-0.105^{\star} \\
(-1.85)\end{array}$ & $\begin{array}{l}-0.106^{\star} \\
(-1.86)\end{array}$ & $\begin{array}{l}-0.139^{\star \star} \\
(-2.32)\end{array}$ & $\begin{array}{l}-0.143^{\star \star} \\
(-2.48)\end{array}$ & $\begin{array}{l}-0.143^{\star \star} \\
(-2.54)\end{array}$ & $\begin{array}{l}-0.154^{\star \star \star} \\
(-2.68)\end{array}$ & $\begin{array}{l}-0.097 \\
(-1.57)\end{array}$ \\
\hline $\begin{array}{l}\text { Control variables } \\
\text { FF 48-industry FE } \\
\text { Year FE }\end{array}$ & $\begin{array}{l}\text { Yes } \\
\text { Yes } \\
\text { Yes }\end{array}$ & $\begin{array}{l}\text { Yes } \\
\text { Yes } \\
\text { Yes }\end{array}$ & $\begin{array}{l}\text { Yes } \\
\text { Yes } \\
\text { Yes }\end{array}$ & $\begin{array}{l}\text { Yes } \\
\text { Yes } \\
\text { Yes }\end{array}$ & $\begin{array}{l}\text { Yes } \\
\text { Yes } \\
\text { Yes }\end{array}$ & $\begin{array}{l}\text { Yes } \\
\text { Yes } \\
\text { Yes }\end{array}$ & $\begin{array}{l}\text { Yes } \\
\text { Yes } \\
\text { Yes }\end{array}$ & $\begin{array}{l}\text { Yes } \\
\text { Yes } \\
\text { Yes }\end{array}$ & $\begin{array}{l}\text { Yes } \\
\text { Yes } \\
\text { Yes }\end{array}$ & $\begin{array}{l}\text { Yes } \\
\text { Yes } \\
\text { Yes }\end{array}$ \\
\hline $\begin{array}{l}\text { No. of obs. } \\
\text { Adj. } R^{2}\end{array}$ & $\begin{array}{l}4,687 \\
0.621\end{array}$ & $\begin{array}{l}4,687 \\
0.621\end{array}$ & $\begin{array}{l}4,687 \\
0.629\end{array}$ & $\begin{array}{l}4,224 \\
0.618\end{array}$ & $\begin{array}{l}4,224 \\
0.618 \\
\end{array}$ & $\begin{array}{l}4,275 \\
0.626 \\
\end{array}$ & $\begin{array}{l}4,235 \\
0.623 \\
\end{array}$ & $\begin{array}{l}4,687 \\
0.621 \\
\end{array}$ & $\begin{array}{l}4,385 \\
0.628 \\
\end{array}$ & $\begin{array}{l}3,052 \\
0.636 \\
\end{array}$ \\
\hline
\end{tabular}


The difference in the offering yield spreads between the bonds with high media coverage $(\mathrm{H})$ and no coverage $(\mathrm{N})$ is 133 basis points, which is highly statistically significant $(t=21.75)$. The difference in the offering yield spreads between the bonds with high $(\mathrm{H})$ and low $(\mathrm{L})$ media coverage is 71 basis points, which is also very significant $(t=12.74)$. These results clearly support Hypothesis 1 and suggest that media coverage has a significantly negative relation to a firm's cost of borrowing.

\section{B. Yield Spreads Regressions}

To examine the role of media coverage more precisely, we run regressions with tighter controls for other variables. Unlike previous studies, we examine the relation of media coverage to the cost of debt using the data based on new bond offering yields at the time of issuance, which better controls for the effects of secondary market factors on bond yields. ${ }^{11}$ In addition, using regression analysis enables us to jointly control for all firm/bond characteristics and channel variables, as well as the time-series effect on term structure, which is difficult to accomplish with portfolio sorts alone.

We run the following regression of offering yield spreads with multiple controls:

$$
\begin{aligned}
\text { YIELD_SPREAD }_{i, t}= & \alpha_{0}+\alpha_{1} \text { MEDIA }_{i, t-1}+\rho \text { CONTROL_X } \\
& +\gamma \text { CONTROL_ } Z+\delta_{j}+\tau_{t}+\varepsilon_{i, t},
\end{aligned}
$$

where $t$ indicates bond offering month, $i$ indexes bond, and $j$ indexes industry. The most important explanatory variable is media coverage in the month prior to the bond issuance. Control $X$ contains the control variables of primary interest to this study: information asymmetry, corporate governance, liquidity, and default risk. To capture the effect of information asymmetry, we use the number of analysts following a firm, and affiliation with reputable investment banks as key variables. For corporate governance, we use board independence and the ISS-Index. In addition, we use stock and bond liquidity measures for liquidity proxies, and Altman's Z-score and Merton's expected default frequency (EDF) for default risk proxies.

Additionally, we include controls for firm/bond characteristics (CONTROL_ $\mathrm{X})$ that may affect media coverage, which include: RETURN, VOLATILITY, FIRM_SIZE, MTB, SHAREHOLDERS, EMPLOYEES, DISPERSION, SEO_ PAST_5Y, BOND_PAST_5Y, BIG_AUDITOR, INSTITUTIONAL, SYNDICATE_ SIZE, SYNDICATE_REPU, and BOARD_SIZE. We also control for the effects of standard determinants of bond yields: RATING, MATURITY, ISSUE_SIZE, LEVERAGE, AGE, ROA and COLLATERAL, labeled as CONTROL_Z in the panel regression. All panel regressions control for Fama-French 48 industry $\left(\delta_{j}\right)$ and year fixed effects $\left(\tau_{t}\right)$. If media coverage is not a proxy for other variables,

\footnotetext{
${ }^{11}$ For example, past studies on the effects of corporate governance, auditor quality, and analyst forecasts on the cost of debt typically make use of transaction yields of seasoned bonds in the secondary market provided by the Lehman Brothers Fixed Income (LBFI) database (see Anderson et al. (2004), Bhojraj and Sengupta (2003), Klock, Mansi, and Maxwell (2005), and Mansi et al. (2004), (2011)). These bond yields are subject to the effects of microstructure factors in the secondary market.
} 
$\alpha_{1}$ in equation (1) should remain significant after controlling for the potential effects of all these other variables.

Panel B of Table 4 reports the results of panel regressions where $t$-values (in parentheses) are based on standard errors, clustered at the issuer level. As shown, $\alpha_{1}$ is highly significant with a negative sign across all regression specifications. Column 1 reports the results with controls for standard determinants (CONTROL_Z) of yields, and firm/bond characteristics that may affect media coverage. The coefficient of media coverage is significantly negative $(-0.144)$ with a $t$-value of -4.27 , implying that on average, an additional unit of media coverage leads to a drop of $14.4 \mathrm{bps}$ in the offering yield spread. This relation is economically significant.

Columns 2-9 of Table 4 further control for the effects of four important economic mechanisms denoted by CONTROL_X. The relation of media coverage to bond offering yields remains highly significant even after controlling for the effects of information asymmetry, corporate governance, liquidity, and default risk. Results suggest that media coverage is not a proxy for these economic variables. Yield spreads are lower for issuers with a larger analyst following, more reputable banks, higher board independence, better corporate governance, higher bond and stock liquidity, and lower default risk (higher Z_SCORE or lower EDF). In column 10, we reestimate regression equation (1) with simultaneous controls for all the channel variables. The coefficient of media coverage remains highly significant, suggesting that media coverage has a significantly negative association with the cost of debt beyond the traditional variables perceived to be important determinants of borrowing cost. ${ }^{12}$

Offering yield spreads are negatively related to past stock returns and positively related to stock return volatility. These results are in line with the prediction of the structural model of corporate bonds (see Campbell and Taksler (2003)). Consistent with the findings of Bhojraj and Sengupta (2003), higher institutional ownership is associated with lower offering yield spreads. ${ }^{13}$ The positive board size coefficient supports the argument that firms with larger boards have poorer communication and weaker monitoring. Importantly, the coefficient of media coverage remains highly significant even after controlling for these variables.

It is noteworthy that the cost of borrowing depends on standard determinants of bond yields (included in CONTROL_Z). Untabulated results (omitted for brevity) show that bonds with worse credit ratings and longer maturities have higher offering yield spreads. Also, bonds issued by high-leverage and younger firms have higher costs of borrowing. Conversely, borrowing cost is negatively related to a firm's operating performance.

Overall, there is strong evidence that media coverage has a significantly negative relation to bond offering yields, and this relation is robust to controlling for various economic channels, bond/firm characteristics, and standard determinants

\footnotetext{
${ }^{12}$ Results (omitted for brevity) show that all channel variables have predicted signs and higher significance for reputable banks, bond and stock liquidity, and EDF.

${ }^{13}$ The positive coefficient of number of shareholders is consistent with the argument that diverse stockownerships weaken the monitoring of managers and therefore, increase the cost of debt (see Kempf, Manconi, and Spalt (2017)).
} 
of bond yields. These results suggest that in a market with imperfect information, the media play a critical role in influencing the cost of debt.

\section{Addressing Concern for Endogeneity}

Firms may have indirect control over media coverage through the size and frequency of their bond and stock issues, uses of reputable investment banks and auditors, and the frequency of their financial performance-related information releases. Also, to the extent that media coverage shapes a firm's characteristics and changes in characteristics affect yield spreads, the media effect may merely proxy for these effects. As an example, more frequent stock and bond offerings increase liquidity and attract media attention. It is possible that stock and bond liquidity are being captured by media coverage and the cost of debt is negatively related to liquidity. Thus, the effect of media coverage could be simply due to the differences in liquidity. In this section, we examine the robustness of our results to endogeneity.

\section{Propensity Score Matching Analysis}

To address potential endogeneity arising from the correlation of media coverage with firm characteristics, we conduct a propensity score matching (PSM) analysis. We first compare the characteristics of issuers with and without media coverage. Panel A of Table 5 shows that mean differences between these variables are overwhelmingly significant. To determine whether media coverage proxies for differences in these characteristics, we conduct a matching sample analysis using the PSM algorithm. In the first stage, we estimate a probit model by regressing a binary media variable on all characteristics in Panel A. The binary dependent variable is a dummy variable indicating whether the issuer is covered in at least 1 newspaper article prior to the bond offering month. In the second stage, we use the first-stage propensity estimates to match bonds of similar characteristics. ${ }^{14}$ Matching is done with a $1: 1$ nearest neighbor methodology without replacement and the caliper set equal to 0.01 (see Rosenbaum and Rubin (1983)). ${ }^{15}$

Panel B of Table 5 reports the diagnostic test for the accuracy of our matching analysis. It shows that all characteristics are insignificantly different after matching the two groups of issuers, suggesting that our matching control is effective for the observed characteristics. Importantly, the yield spread (row 1) is 15 basis points lower for issuers with media coverage, which is significant at the $5 \%$ level $(t=2.09)$ even after we impose stringent control for the characteristics

\footnotetext{
${ }^{14}$ Specifically, given the predicted propensity scores, we match each bond without media coverage to a bond with coverage with similar characteristics that minimizes the absolute difference between the propensity scores within the same industry-year. Industry matching is required before selecting the best match using propensity scores.

${ }^{15}$ The caliper is a maximum distance (radius) restriction on control variables (characteristics) selected to match a treated observation. We choose 1:1 matching as this procedure is commonly accepted in the literature (see Michaely and Roberts (2012), Chan, Chen, and Chen (2013), and Kirk and Vincent (2014)). Our sample consists of more bonds with media coverage (3,414 bonds) than without media coverage (1,924 bonds). For each bond without newspaper coverage, we can easily choose 1 bond with media coverage and similar characteristics to have the best match. We also extend the number of nearest neighbors in matching from 1 to 2 and use matching with replacement. Our results are robust to these alternative methods.
} 
TABLE 5

PSM Estimation

\begin{tabular}{|c|c|c|c|c|c|c|c|c|}
\hline & \multicolumn{4}{|c|}{ Panel A. Before Matching Coverage } & \multicolumn{4}{|c|}{ Panel B. After Matching Coverage } \\
\hline & $\begin{array}{c}\text { With } \\
\text { Media } \\
\end{array}$ & $\begin{array}{l}\text { Without } \\
\text { Media } \\
\end{array}$ & Diff. & $t$-Value & $\begin{array}{c}\text { With } \\
\text { Media } \\
\end{array}$ & $\begin{array}{l}\text { Without } \\
\text { Media } \\
\end{array}$ & Diff. & $t$-Value \\
\hline YIELD_SPREAD & 1.53 & 2.49 & 0.96 & (23.59) & 1.69 & 1.84 & 0.15 & (2.09) \\
\hline RATING & 6.41 & 10.10 & 3.69 & $(36.74)$ & 7.33 & 7.10 & -0.23 & $(-0.72)$ \\
\hline MATURITY & 11.20 & 10.00 & -1.20 & $(-5.63)$ & 10.85 & 10.22 & -0.63 & $(-0.90)$ \\
\hline COLLATERAL & 0.21 & 0.08 & -0.13 & $(-12.38)$ & 0.14 & 0.19 & 0.05 & $(1.45)$ \\
\hline FIRMSIZE & 21.40 & 5.21 & -16.19 & $(-28.61)$ & 11.16 & 9.94 & -1.22 & $(-1.09)$ \\
\hline LEVERAGE & 0.63 & 0.63 & 0.00 & $(-0.96)$ & 0.64 & 0.62 & -0.02 & $(-0.70)$ \\
\hline AGE & 39.00 & 25.40 & -13.60 & $(-20.89)$ & 35.15 & 33.96 & -1.18 & $(0.53)$ \\
\hline $\mathrm{ROA}$ & 0.05 & 0.04 & -0.01 & $(-7.68)$ & 0.07 & 0.07 & -0.00 & $(-0.21)$ \\
\hline BOARDIND & 0.52 & 0.60 & 0.08 & (9.33) & 0.63 & 0.60 & -0.03 & $(-1.14)$ \\
\hline ISS_INDEX & 11.30 & 11.60 & 0.30 & (4.08) & 12.08 & 11.95 & -0.14 & $(-0.74)$ \\
\hline ISSŪE_SIZE & 616.00 & 414.00 & -202.00 & $(-13.04)$ & 507.40 & 447.40 & -60.04 & $(-1.24)$ \\
\hline BOND_LIQ & 2.02 & 1.90 & -0.12 & $(-3.93)$ & 1.97 & 2.07 & 0.11 & (1.15) \\
\hline STOCK_LIQ & 11.40 & 10.40 & -1.00 & $(-22.62)$ & 11.21 & 10.85 & -0.36 & $(-1.57)$ \\
\hline ANALYSTS & 22.90 & 14.30 & -8.60 & $(-34.72)$ & 18.65 & 17.90 & -0.75 & $(-0.87)$ \\
\hline REPU_IVBANK & 0.78 & 0.70 & -0.08 & $(-6.63)$ & 0.74 & 0.75 & 0.01 & $(0.22)$ \\
\hline Z_SCORE & 1.65 & 1.46 & -0.19 & $(-5.75)$ & 1.66 & 1.68 & 0.02 & $(0.38)$ \\
\hline $\mathrm{EDF}$ & 0.08 & 0.11 & 0.03 & $(4.70)$ & 0.07 & 0.06 & -0.01 & $(-0.62)$ \\
\hline RETURN & 0.06 & 0.08 & 0.03 & (8.63) & 0.06 & 0.07 & 0.01 & (1.33) \\
\hline VOLATILITY & 2.15 & 2.54 & 0.39 & (14.54) & 2.35 & 2.26 & -0.10 & $(-1.11)$ \\
\hline MTB & 1.74 & 1.59 & -0.15 & $(-8.55)$ & 1.79 & 1.77 & -0.02 & $(-0.33)$ \\
\hline SHAREHOLDERS & 128.85 & 20.80 & -108.05 & $(-21.59)$ & 53.71 & 52.65 & -1.06 & $(-0.33)$ \\
\hline EMPLOYEES & 103.38 & 26.50 & -76.88 & $(-25.02)$ & 59.05 & 58.56 & -0.49 & $(-0.09)$ \\
\hline DISPERSION & 0.23 & 0.22 & -0.02 & $(-1.92)$ & 0.22 & 0.17 & -0.05 & $(-0.06)$ \\
\hline SEO_PAST_5Y & 0.12 & 0.16 & 0.04 & $(4.51)$ & 0.24 & 0.22 & -0.02 & $(-1.14)$ \\
\hline BOND_PAST_5Y & 2.16 & 0.51 & -1.65 & $(-25.96)$ & 0.87 & 0.85 & -0.03 & $(-0.58)$ \\
\hline BIGAUDITOR & 0.81 & 0.76 & -0.05 & $(-5.32)$ & 0.69 & 0.68 & -0.01 & $(-0.19)$ \\
\hline INSTITUTIONAL & 0.67 & 0.72 & 0.05 & $(9.24)$ & 0.72 & 0.73 & 0.01 & $(0.20)$ \\
\hline SYNDICATE_SIZE & 6.91 & 5.18 & -1.73 & $(-6.86)$ & 7.28 & 6.94 & -0.34 & $(-0.35)$ \\
\hline SYNDICATE_REPU & 0.27 & 0.19 & -0.08 & $(-6.39)$ & 0.25 & 0.28 & 0.03 & $(1.40)$ \\
\hline BOARD_SIZĒ & 9.05 & 8.67 & -0.38 & $(-4.59)$ & 9.58 & 9.48 & -0.10 & $(-0.32)$ \\
\hline
\end{tabular}

in the PSM model. The results suggest that media coverage does not proxy for changes in firm characteristics and endogeneity is not a serious concern.

\section{Instrumental Regression Analysis}

Another approach to addressing endogeneity is to estimate an instrumental variable regression. Here we use the number of news reporters and correspondents per capita in the firm's headquarter state as an instrument for media productivity. As variations in the employment of this professional group are driven predominantly by state macroeconomic conditions, the number of reporters and correspondents per capita in each state is an effective instrument for media coverage. This variable has several desirable features: i) It is strongly positively correlated with media coverage, ii) it does not affect yield spreads directly, and iii) it is unlikely to be correlated with the omitted variables affecting yield spreads since theory offers no obvious direct economic connection.

We manually collect the data of state-level media workers from the Bureau of Labor Statistics under the category labeled Reporters and Correspondents, which covers employees who collect and analyze facts about newsworthy events through 
interviews, investigation, or observation, and report or write stories for newspapers, news magazines, radio, or television. We use the number of news reporters per 1,000 people in each state as our instrumental variable. ${ }^{16}$

Column 1 of Table 6 reports the result of the first-stage regression in a standard 2-stage regression model in order to identify the unbiased media effect on the cost of debt. For brevity, we report only the parameter estimates of reporters per capita. We find that this instrumental variable has a highly significant positive relation $(t=3.92)$ with the media coverage of issuers located in that state. The $F$-statistic of the Staiger-Stock (1997) test is greater than 10, which rejects the weak-instrument null hypothesis. In the second-stage equation, we use the predicted value of media coverage from the first-stage regression as an explanatory variable in the yield spread regression to provide a consistent estimate of the media coverage coefficient. Again for brevity, we only report the parameter estimates of the predicted media coverage. Column 2 shows that the coefficient of media coverage is significantly negative. The results show robustness in the relation between media coverage and bond offering yields to this endogeneity adjustment.

We also investigated several other methods ${ }^{17}$ to address the issue of endogeneity and find similar results. However, econometric methods have limitations and as is true with most studies, we may not have fully resolved the endogeneity concerns due to possible omitted variables or an imperfect instrument. While we cannot claim causality based on a standard regression analysis, empirical regularities that we have uncovered in our analysis seem sufficiently strong and robust to suggest the importance of the potential effect of media coverage on the cost of debt.

\section{TABLE 6}

\section{Number of Reporters Per Capita by State as the Instrumental Variable}

Table 6 reports the 2-stage least squares (2SLS) instrumental variable regressions on media effects to correct the endogeneity estimation bias. \#_REPORTERS_PER_CAPITA, collected from the U.S. Bureau of Labor Statistics, is the number of reporters per 1,000 people in each state, and serves as an instrumental variable. The first column reports the first-stage regression estimation on the relations between the instrument variable and media coverage. The second column reports the second-stage regression estimations on the relations between predicted media coverage and yield spreads with control variables, which include all other variables except media coverage, as used in Table 4. All variables included are defined in Appendix A. Year and Fama-French (FF) 48 industry fixed effects are included in all regressions. The $t$-values, based on standard errors clustered at issuer level, are reported in parentheses. Cragg-Donald Wald $F$-statistics for weak identification tests are reported. * ${ }^{* *}$, and ${ }^{* * *}$ indicate significance at the $10 \%, 5 \%$, and $1 \%$ levels, respectively.

\begin{tabular}{lcc} 
& $\begin{array}{c}\text { 1st Stage Regression: } \\
\text { MEDIA }\end{array}$ & $\begin{array}{c}\text { 2nd Stage Regression: } \\
\text { YIELD_SPREAD }\end{array}$ \\
\cline { 2 - 2 } \#_REPORTERS_PER_CAPITA & $\begin{array}{c}0.411^{\star \star \star} \\
(3.92)\end{array}$ & \\
PREDICTED_MEDIA & & $-3.882^{\star \star \star}$ \\
Control variables & & $(-4.09)$ \\
FF 48-industry fixed effects & Yes & Yes \\
Year fixed effects & Yes & Yes \\
No. of obs. & 5,338 & 3,052 \\
Wald $F$-stat. & & 35.44 \\
Adj. $R^{2}$ & 0.325 & \\
\hline
\end{tabular}

\footnotetext{
${ }^{16}$ The distribution of reporters by state is shown in Table B1 in Appendix B.

${ }^{17}$ These include the Heckman 2-stage method and using lagged and orthogonal media coverage variables.
} 


\section{Channels of Potential Media Coverage Effects}

We next investigate the channels through which media coverage can operate to influence the cost of debt. To this end, we conduct a portfolio analysis, followed by a regression analysis.

\section{Bivariate Portfolio Sorts}

To track the effect of each economic channel, we perform bivariate portfolio sorts. Bonds are first sorted into high and low groups by a measure for each channel variable listed in Panel B of Table 4. To capture the effect of the information asymmetry channel, we divide firms into groups that do (Yes) and do not (No) hire more reputable investment banks. Within each group, we further divide the bonds into portfolios with noncovered $(\mathrm{N})$, and low $(\mathrm{L})$ and high $(\mathrm{H})$ media coverage. We then calculate the mean differences in yield spreads between no-coverage and high-coverage portfolios $(\mathrm{N}-\mathrm{H})$ and between low- and high-coverage portfolios (L-H).

Panel A of Table 7 reports the results of the bivariate portfolio sorts. The $t$-statistics for testing the difference in mean offering yield spreads of portfolios are reported in parentheses. The top of this panel (Panel A1) shows the results of portfolio sorts associated with the information asymmetry channel. Consistent with the literature, the yield spread is smaller for bonds issued by firms with a larger analyst following and employing brand name investment banks. ${ }^{18}$ Thus, the media can indirectly influence debt yields through the information asymmetry channel (Bushee et al. (2010), Cassar et al. (2014)). Bonds with high media coverage have significantly lower offering yield spreads across the groups (e.g., significantly positive N-H and L-H spreads), even after controlling for the number of analysts following the firm and the investment bank's reputation. Results suggest that media coverage does not proxy for the effect of these variables.

Panel A2 of Table 7 reports the results of controlling for the effects of corporate governance. Consistent with the prior literature examining the effects of corporate governance on the cost of debt (Bhojraj and Sengupta (2003), Anderson et al. (2004), and Klock et al. (2005)), bonds issued by firms with better governance have lower yield spreads. Thus, by improving corporate governance, media coverage can exert an influence on bond yields. All the yield spread differences associated with media coverage (N-H and L-H) remain positive and highly significant after controlling for the effects of overall corporate governance and board quality. This suggests that media coverage has an independent influence on bond yields beyond that of corporate governance. The negative relation between media coverage offering yield spreads is stronger for poorly governed firms.

Panel A3 of Table 7 shows the results of controlling for the effects of bond and stock liquidity. In line with the liquidity literature, bonds with lower liquidity have higher yield spreads (Bongaerts et al. (2017)). As bonds issued by firms with high media coverage have high liquidity, media coverage can work through the liquidity channel to influence bond yields. Controlling for liquidity,

\footnotetext{
${ }^{18}$ Auditor quality and reputation or size of syndicates play a similar role to reputable banks and results are robust.
} 
TABLE 7

Channels of the Media Coverage Effect on Offering Yield Spreads

Table 7 reports channels of the media coverage effect on offering yield spreads. The sample consists of 5,338 observations, over the period 1990-2011. Panel A shows the bivariate sorts by channel variables and media coverage. We first sort bonds into 2 subgroups by each control variable every year, and then further divide the bonds in each subgroup into three portfolios by media coverage (i.e. Noncovered $(\mathrm{N})$, Low (L), and High (H) portfolios). Panel B presents the yield spread regression results with the interactions of information asymmetry, corporate governance, liquidity, and default risk with media coverage. The dependent variable is YIELD_SPREAD. MEDIA $\times \Delta$ is the main explanatory variable of interest, defined as the interaction between media coverage and $\Delta$, where $\Delta$ is a dummy variable with a value of 1 if a target channel variable is higher than the median of information asymmetry, corporate governance, liquidity, or default risk variable, and 0 otherwise. Panel $\mathrm{C}$ reports the regression results, including all 4 key determinants of yield spreads. The constants and other control variable coefficients are omitted for brevity. All other variables, with the exception of media coverage, used in Table 4 are included in the regression (denoted as control variables). The variables included in the regressions are defined in Appendix A. Year and Fama-French (FF) 48 industry fixed effects are included in all regressions and $t$-values based on standard errors clustered at issuer level are reported in parentheses. ${ }^{*},{ }^{* *}$, and ${ }^{* * *}$ indicate the significance at the $10 \%, 5 \%$, and $1 \%$ levels, respectively.

$\underline{\text { Panel A. Bivariate Portfolio Sorts }}$

Panel A1. Information Asymmetry ANALYSTS (Lower)

ANALYSTS (Higher)
REPU IVBANK (Lower)

REPU_IVBANK (Lower)

Panel A2. Corporate Governance

BOARDIND (Lower)

BOARDIND (Higher)

ISS_INDEX (Lower)

ISS_INDEX (Higher)

Panel A3. Liquidity

BOND_LIQ (Lower)

BOND_LIQ (Higher)

STOCK_LIQ (Lower)

STOCK_LIQ (Higher)

Panel A4. Credit Risk

Z_SCORE (Lower)

Z_SCORE (Higher)

EDF (Lower)

EDF (Higher)

\begin{tabular}{c} 
Noncovered \\
\hline \\
2.67 \\
1.96 \\
2.74 \\
2.37 \\
\\
2.32 \\
2.26 \\
2.17 \\
1.81 \\
\\
2.92 \\
2.02 \\
2.65 \\
2.00 \\
\\
2.63 \\
2.06 \\
1.66 \\
3.00
\end{tabular}

3.00

\begin{tabular}{l} 
Low \\
\hline 2.08 \\
1.44 \\
2.04 \\
1.65 \\
\\
1.91 \\
1.45 \\
2.02 \\
1.54 \\
\\
2.05 \\
1.53 \\
1.88 \\
1.70 \\
\\
1.91 \\
1.43 \\
1.12 \\
2.35
\end{tabular}

Low

2.08

1.44
2.04

65

1.91
1.45

1.45

1.54

2.05

1.53
1.88

1.70

1.91
1.43

1.43
1.12
High

1.77

1.12
1.67

1.41

1.45
1.08

1.08
1.18

1.18

1.52

1.13

1.28
1.12

1.38
0.95

1.38
0.79

0.79
$\mathrm{N}-\mathrm{H}$

$0.91^{\star \star *}$

$0.84^{\star \star *}$

$1.06^{\star \star \star}$
$0.97^{\star \star *}$

$0.87^{\star \star *}$

$0.87^{\star \star \star}$
$0.81^{\star \star \star}$

$0.99^{\star \star *}$

$0.88^{\star \star *}$

$1.40^{* \star *}$

$0.89^{\star \star \star *}$

$1.37^{\star \star \star}$
$0.88^{\star \star \star}$

$1.25^{\star \star \star}$
$1.10^{\star \star \star}$
$0.87^{\star \star \star}$

$0.87^{\star \star \star}$
$t$-Value

(12.03)

$(12.40)$

$(12.20)$
$(10.55)$

$(15.16)$
$(10.43)$

$(10.43)$
$(9.05)$
$(7.84)$

(7.84)

(16.73)

(14.71)

$(17.96)$
(13.18)

(18.66)

$(14.51)$
$(18.84)$

$(18.84)$
(15.09)
$\underline{\mathrm{L}-\mathrm{H}}$

$0.31^{\star * *}$

$0.31^{\star \star \star \star}$

$0.37^{\star \star *}$
$0.25^{\star * *}$

$0.46^{\star * *}$

$0.46^{\star \star \star *}$

$0.37^{\star \star \star *}$

$0.60^{\star * \star}$

$0.54^{\star * *}$

$0.39^{* * *}$

$0.60^{\star \star \star}$

$0.58^{\star \star \star}$

$0.53^{\star \star *}$
$0.48^{\star \star \star}$

$0.48^{\star \star \star}$

$0.33^{\star \star \star}$
$0.49^{\star \star \star}$

(6.57) 
TABLE 7 (continued)

Channels of the Media Coverage Effect on Offering Yield Spreads

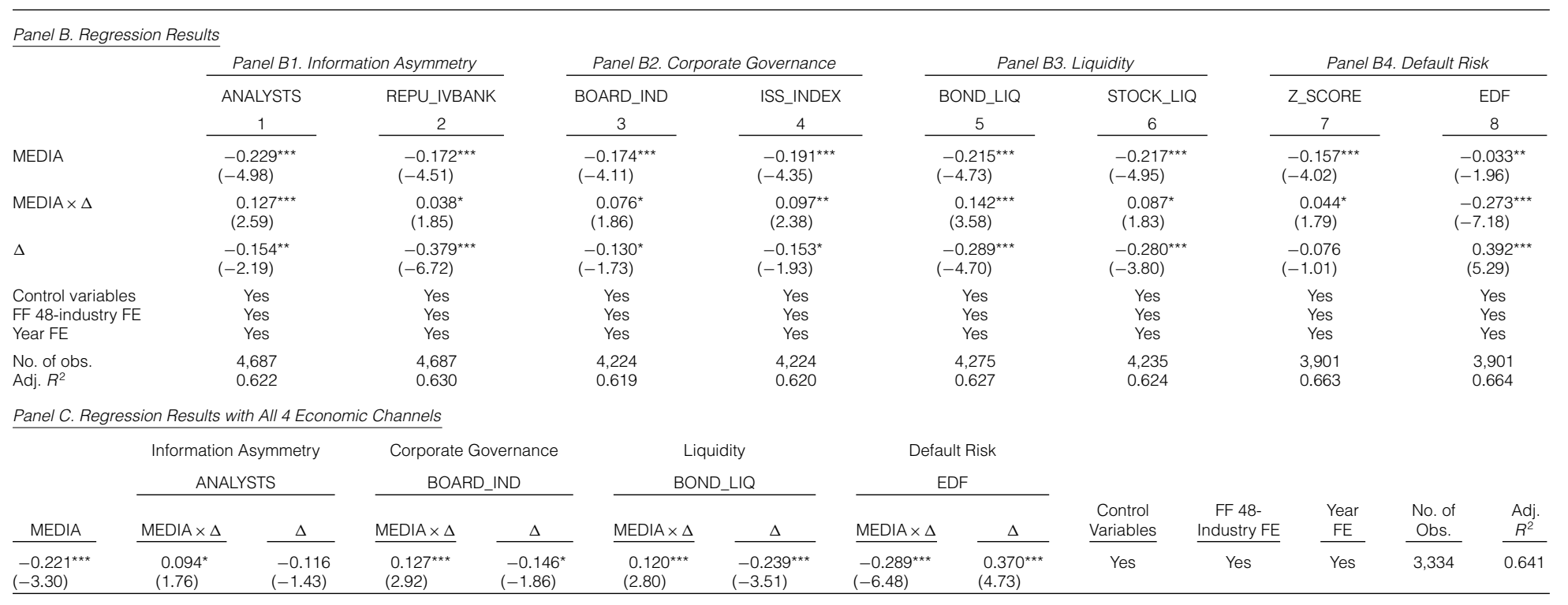


bonds with high media coverage continue to have significantly lower offering yields than those with low media coverage or no coverage. This negative relation is stronger for firms with lower liquidity.

Panel A4 of Table 7 reports the results of controlling for the effect of default risk. Consistent with the theory of the term structure of risky corporate bonds, the yield spread is higher for bonds issued by firms with higher default risk. Media coverage can therefore influence debt yields by reducing default risk (Bhojraj and Sengupta (2003)). Importantly, bonds with high media coverage continue to have significantly lower yield spreads, even after controlling for the effects of default risk, and this negative relation is stronger for firms with higher default risk.

\section{Regression Analysis}

The preceding analysis shows that the influence of media coverage is robust to controls for firm/bond attributes and standard determinants of bond yields. A remaining question is how greater media coverage causes the cost of debt to fall. To answer this question, we examine plausible channels through which media coverage influences the cost of debt using regression analysis. Specifically, we run the following ordinary least squares (OLS) regressions with the interaction of media coverage and each main channel variable in equation (2):

$$
\begin{aligned}
\text { YIELD_SPREAD }_{i, t}= & \alpha_{0}+\alpha_{1} \text { MEDIA }_{i, t-1}+\alpha_{11} \operatorname{MEDIA}_{i, t-1} \times \Delta \\
& +\beta \text { CONTROLS }+\delta_{j}+\tau_{t}+\varepsilon_{i, t},
\end{aligned}
$$

where we employ all other explanatory variables in Table 4 as controls. The dummy variable $(\Delta)$ takes a value of 1 if the targeted channel variable is larger than the sample firm median of that variable in a given year, and 0 otherwise. Again, we calculate the $t$-values based on the standard errors clustered at the issuer level and account for the year $\left(\tau_{t}\right)$ and industry $\left(\delta_{j}\right)$ fixed effects.

Columns 1 and 2 of Panel B in Table 7 report the results for regressions controlling for the information asymmetry channel, where we use analyst coverage and underwriter reputation as the main explanatory variables. For brevity, we only report the parameter estimates for the variables of primary interest (i.e., media coverage, the channel measures, and their interactions). As indicated, the coefficients of the interaction variables are all positive and significant, suggesting that media impact is greater for firms with lower analyst coverage and less reputable investment banks. Results show that the media relation to the cost of debt is stronger for firms with higher information asymmetry. This evidence lends support to Hypothesis 2.

To test the media's governance role, we run regressions with the interactions for the governance variables and media coverage. Columns 3 and 4 of Panel B show that the coefficients of interaction terms are significantly positive, indicating that the relation of media coverage to the cost of debt is stronger for issuers with poor governance and board quality. These results support Hypothesis 3, indicating that an important channel through which media coverage appears to reduce the cost of debt capital is by improving a firm's corporate governance.

To investigate the liquidity and default risk channels of media coverage, we run regressions on the interactions of these variables with media coverage. Columns 5 and 6 of Panel B in Table 7 report the regression results associated 
with the liquidity channel. The coefficients of both interaction variables of liquidity and media coverage are significantly positive. Results support Hypothesis 4, which posits that the relation of media coverage to the cost of debt is stronger for issuers with lower liquidity. Columns 7 and 8 show that the coefficients of interactions between media coverage and default risk all have their expected signs and are significant. The results further support Hypothesis 4, which states that the marginal impact of media coverage is stronger for firms with higher default risk. Thus, both liquidity and default risk appear to be viable channels through which media coverage can influence bond offering yields.

Finally, Panel $\mathrm{C}$ of Table 7 reports the results of regressions that include all four economic channels. To mitigate collinearity, we choose only 1 variable for each economic channel. Again, for brevity, we only report the estimates of key variables. The results show that all interaction variables are significant with predicted signs. Most important, media coverage remains highly significant $(t=-3.30)$ even after controlling for all channel variables and firm/bond characteristics. This suggests that media coverage has direct effect on bond yield spreads.

\section{E. Additional Evidence}

In this section, we provide additional evidence that our finding on the impact of media coverage is robust to the selection of different firm subsamples and alternative measures of information asymmetry. Young firms with recent IPOs typically have high information asymmetry, compared to more seasoned firms. The literature has shown that IPO firms characterized by higher information asymmetry tend to be more underpriced (Rock (1986), Beatty and Ritter (1986)) and have higher return volatility initially (Lowry, Officer, and Schwert (2010)). A firm's information asymmetry generally falls with stock seasoning over the first few years after an IPO, as evidenced by declined stock return volatility (Barth et al. (2017)). To explore the relation of media coverage to debt yields for young firms, we select firms that have had an IPO in the past 3 years, and compare them with more seasoned firms. We then focus on IPOs of firms that initially incorporate in the past 10 years prior to the IPO date in an attempt to rule out long-lived private firms, spinoffs, carve-outs, and reverse leveraged buyouts (LBOs) (Cao and Lerner (2009), Bharath and Dittmar (2010)). We expect the results to be stronger for this potentially cleaner subsample.

Columns 1 and 2 of Table 8 report the results for subsamples of young firms that have had an IPO in the past 3 years and more seasoned firms, respectively. The media coverage coefficient of the IPO firms is more than 3 times that of more seasoned firms, suggesting that the impact of media coverage is much greater for these young firms. Columns 3 and 4 report the results for the IPO firms that have initially incorporated in the prior 10 years, versus other more seasoned firms. These results show an even larger (absolute) coefficient of media coverage for the more recently incorporated subsample.

We next investigate the issue of the reliability of information asymmetry measures. To check the robustness of our results to different information asymmetry measures, we consider three alternative information asymmetry proxies based on intangible asset intensity, time-series correlation of the firm's stock returns 
with its industry stock returns, and discretionary accruals. High intangible asset intensity, in terms of the level of firm transparency, and low time-series correlation with industry returns imply high information asymmetry. In addition, firms with high discretionary accruals tend to have less reliable accounting information (see Biggerstaff, Cicero, and Puckett (2015)). We run regressions with these variables by including a dummy variable $(\Delta)$ that has a value of 1 when the target variable is above the median of the sample firms, and 0 otherwise.

Columns 5-7 of Table 8 show that media coverage and the interaction terms are all significant for the three information asymmetry proxies. The relation between media coverage and debt cost remains negative. This relation is stronger for firms with high intangible asset intensity and discretionary accruals, and exhibits a low correlation with the industry. In columns 8 and 9, we further report the results of using institutional ownership and firm size as additional proxies for information asymmetry. We find that the relation between media coverage and debt cost is also stronger for smaller firms, as well as firms with lower institutional ownership.

These results support Hypotheses 2 and 4, which posit that the influence of media coverage is stronger for firms with higher information asymmetry and less reliable accounting information. Relative to other information asymmetry measures, media coverage becomes more important when using the stock return correlation with the industry return as a proxy for information asymmetry.

Overall, there is evidence that the potential media coverage effect can in part work through different economic channels. This finding is robust to different measures of information asymmetry and accounting quality (reliability), and to various subsamples. Media coverage can partially substitute for institutional monitoring, board effectiveness, and other intermediary information sources. Media coverage influence is also stronger for firms with lower liquidity and higher default risk, for small firms and young firms with recent IPOs, and IPO firms that are recently incorporated.

\section{F. Media Coverage and Flotation Costs}

In capital markets, underwriters perform two important functions. First, underwriters can provide fully marketed offers to issuers to create demand for their new securities through promotions (see Gao and Ritter (2010)). Second, underwriters can bridge issuers and investors by reducing information asymmetry between these two parties. In exchange for these valuable services, the issuer pays a fee. As media perform similar functions of increasing the demand for a firm's security and alleviating information asymmetry, this raises the issue of whether media coverage may reduce the value of the intermediation services by investment banks, thereby exerting a pressure to lower underwriting fees. In this section, we investigate this issue using bond underwriting data.

To ascertain the relation between media coverage and flotation costs, we estimate regressions of underwriter gross spreads (in percentage) against media coverage and other controls. The dependent variable GROSS_SPREAD is the sum of the underwriter fee, management fee, and selling concessions, divided by the total issue size for public debt issues. Besides standard determinants of underwriter fees (see Fang (2005)), we control for the effects of underwriter and 
auditor quality, the size and reputation of a firm's loan syndicates, bond issue size, and credit ratings in the flotation cost regression. The panel regression again accounts for the year and industries fixed effects.

Column 1 in Table 9 shows that the coefficient $(-0.582)$ of media coverage is negative and highly significant $(t=-5.24)$ when used as the sole explanatory variable. The size of the media coverage coefficient decreases, but remains significant after controlling for the effects of conventional underwriting fee determinants, underwriter and auditor quality, loan syndicate size and syndicate lead reputation, issue size, ratings, and other characteristics (see column 2). The results show that media coverage has a negative relation with the underwriting cost of public debt. This finding suggests that media coverage can potentially reduce the flotation cost of public debt.

\section{TABLE 9}

\section{Media Effect on Flotation Costs}

Table 9 reports the OLS regression results on the relation between media coverage and flotation cost. The sample consists of 1,320 observations over the period of 1990-2011. Column 1 reports the univariate regression results and column 2 reports the multivariate regression results. The dependent variable is GROSS_SPREAD, which includes the underwriter fee, the management fee, and selling concessions. MEDIA is the main explanatory variable, defined as the natural logarithm of 1 plus the number of newspaper articles during the month prior to bond issuing. All other variables included in the regressions are defined in Appendix A. Year and Fama-French (FF) 48 industry fixed effects are included in all regressions. The $t$-values based on standard errors clustered at issuer level are reported in parentheses. ${ }^{*},{ }^{* *}$, and ${ }^{* \star *}$ indicate the significance at the $10 \%, 5 \%$, and $1 \%$ levels, respectively.

\begin{tabular}{|c|c|c|}
\hline & \multicolumn{2}{|c|}{ GROSS_SPREAD } \\
\hline & 1 & 2 \\
\hline MEDIA & $\begin{array}{l}-0.582^{\star \star \star} \\
(-5.24)\end{array}$ & $\begin{array}{l}-0.206^{*} \\
(-1.74)\end{array}$ \\
\hline RATING & & $\begin{array}{l}0.115^{* *} \\
(2.09)\end{array}$ \\
\hline MATURITY & & $\begin{array}{c}0.037 \\
(0.38)\end{array}$ \\
\hline COLLATERAL & & $\begin{array}{l}-0.096 \\
(-0.55)\end{array}$ \\
\hline ISSUE_SIZE & & $\begin{array}{l}-1.743^{\star \star \star} \\
(-18.88)\end{array}$ \\
\hline RELATIVE_SIZE & & $\begin{array}{l}1.629^{\star \star \star} \\
(3.09)\end{array}$ \\
\hline FIRMSIZE & & $\begin{array}{l}0.134 \\
(0.81)\end{array}$ \\
\hline LEVERAGE & & $\begin{array}{r}0.655 \\
(0.67)\end{array}$ \\
\hline MTB & & $\begin{array}{l}-0.017 \\
(-0.09)\end{array}$ \\
\hline RETURN & & $\begin{array}{l}-0.558 \\
(-0.63)\end{array}$ \\
\hline VOLATILITY & & $\begin{array}{l}0.120^{*} \\
(1.66)\end{array}$ \\
\hline SYNDICATE_SIZE & & $\begin{array}{r}0.057 \\
(0.57)\end{array}$ \\
\hline SYNDICATE_REPU & & $\begin{array}{r}0.467 \\
(1.58)\end{array}$ \\
\hline REPU_IVBANK & & $\begin{array}{c}0.182 \\
(0.87)\end{array}$ \\
\hline BIG_AUDITOR & & $\begin{array}{l}0.473^{*} \\
(1.73)\end{array}$ \\
\hline $\begin{array}{l}\text { FF 48-industry fixed effects } \\
\text { Year fixed effects }\end{array}$ & $\begin{array}{l}\text { Yes } \\
\text { Yes }\end{array}$ & $\begin{array}{l}\text { Yes } \\
\text { Yes }\end{array}$ \\
\hline $\begin{array}{l}\text { No. of obs. } \\
\text { Adj. } R^{2}\end{array}$ & $\begin{array}{l}1,320 \\
0.131\end{array}$ & $\begin{array}{l}1,320 \\
0.350\end{array}$ \\
\hline
\end{tabular}




\section{Robustness Tests}

In this section, we conduct additional tests for robustness. We explore potential nonlinear relationships between yield spreads and media coverage, and check the robustness of our results to alternative media coverage measures. Moreover, we adjust for the industry effect by controlling for the industry $\times$ year fixed effects in the panel regression to avoid estimation bias.

\section{A. Nonlinear Functional Forms}

Following the convention in media information studies, our results are based on linear regressions. However, it is possible that the relation of media coverage to bond yields may be nonlinear. In such a case, the linear specification is just a first order approximation. For example, the media coverage effect could be subject to the law of diminishing returns. If a firm is covered by only 1 article, then that article is likely to have a large impact. Any additional articles on the firm are expected to have less impact since people are likely to have seen the other article or the journalist may have less information to add after writing the first article. Thus, the marginal effect of media coverage could be declining.

To allow for a nonlinear relationship, we add a quadratic term for media coverage, MEDIA ${ }^{2}$, in the regression. Columns 1 and 2 of Table 10 report the results. For brevity, we only report the parameters associated with media coverage. The squared term of media coverage has a significantly positive coefficient, while the coefficient of MEDIA remains significantly negative, regardless of whether we include control variables or not. Results point to a possible nonlinear relationship. Nevertheless, the main relation between media coverage and the cost of debt continues to be significantly negative, even after allowing for the nonlinear relationship. ${ }^{19}$

To further explore the form of potential nonlinearity, we introduce 2 dummy variables: MEDIA_HIGH, which is a binary variable indicating firms within the top $25 \%$ media coverage (more coverage), and MEDIA_LOW, which represent firms in the bottom $25 \%$ of media coverage. We estimate OLS regressions of yield spreads against these 2 dummy variables with and without other control variables. The last 2 columns show that high media coverage issuers consistently have relatively low yield spreads, whereas low media coverage issuers have relatively high yield spreads. Results reveal an asymmetric relationship between offering yield spreads and media coverage.

We also investigate another type of nonlinear relationship using the natural $\log$ functional form and find our results (omitted for brevity) are robust to this specification. Overall, the impact of media coverage holds up, even after allowing for different plausible nonlinear functional forms. Although the linear regression model used in this study may not fully eliminate any further effects of standard determinants of debt yields, the results suggest that our main finding, based on a standard linear specification, is robust to alternative specifications and functional forms.

\footnotetext{
${ }^{19}$ The coefficients imply a turning point at a high level of media coverage that is outside the range in our sample.
} 
TABLE 10

Nonlinear Regressions

Table 10 reports the results of nonlinear regressions. All other variables, with the exception of media coverage, used in Table 5 are included in the regressions here (denoted as control variables). The dependent variable is offering yield spreads. Columns 1 and 2 report the results with MEDIA ${ }^{2}$, while columns 3 and 4 show results with the firms in the top and bottom $25 \%$ volume of media coverage to allow for the nonlinear effect. MEDIA ${ }^{2}$ is the squared media coverage, measured by the natural logarithm of 1 plus the number of newspaper articles during 1 month prior to bond issuing. The variables included in the regressions are defined in Appendix A. Year and Fama-French (FF) 48 industry fixed effects are controlled in all regressions. The $t$-values based on standard errors clustered at the issuer level are in parentheses, and ${ }^{*},{ }^{* *}$, and ${ }^{* * *}$ indicate the significance at the $10 \%, 5 \%$, and $1 \%$ levels, respectively.

\begin{tabular}{|c|c|c|c|c|}
\hline & 1 & 2 & 3 & 4 \\
\hline MEDIA & $\begin{array}{l}-1.948^{* \star *} \\
(-10.97)\end{array}$ & $\begin{array}{l}-1.334^{\star \star \star} \\
(-8.50)\end{array}$ & & \\
\hline MEDIA $^{2}$ & $\begin{array}{l}0.366^{\star \star \star} \\
(7.72)\end{array}$ & $\begin{array}{l}0.254^{\star \star \star} \\
(6.29)\end{array}$ & & \\
\hline MEDIA_HIGH & & & $\begin{array}{l}-0.473^{\text {** }} \\
(-4.70)\end{array}$ & $\begin{array}{l}-0.230^{* *} \\
(-2.43)\end{array}$ \\
\hline MEDIA_LOW & & & $\begin{array}{l}0.715^{\star \star \star} \\
(8.69)\end{array}$ & $\begin{array}{l}0.373^{\star * *} \\
(5.18)\end{array}$ \\
\hline $\begin{array}{l}\text { Control variables } \\
\text { FF } 48 \text {-industry fixed effects } \\
\text { Year fixed effects }\end{array}$ & $\begin{array}{l}\text { No } \\
\text { Yes } \\
\text { Yes }\end{array}$ & $\begin{array}{l}\text { Yes } \\
\text { Yes } \\
\text { Yes }\end{array}$ & $\begin{array}{l}\text { No } \\
\text { Yes } \\
\text { Yes }\end{array}$ & $\begin{array}{l}\text { Yes } \\
\text { Yes } \\
\text { Yes }\end{array}$ \\
\hline $\begin{array}{l}\text { No. of obs. } \\
\text { Adj. } R^{2}\end{array}$ & $\begin{array}{l}3,414 \\
0.455\end{array}$ & $\begin{array}{l}2,856 \\
0.695\end{array}$ & $\begin{array}{l}3,414 \\
0.371\end{array}$ & $\begin{array}{l}2,856 \\
0.666\end{array}$ \\
\hline
\end{tabular}

\section{B. Robustness to Industry Effects and Alternative Media Coverage Variables}

The estimation of the media coverage coefficient in the regression could be biased by common industry factors. To adjust for the possible industry effect, we control for industry $\times$ year fixed effects in panel regressions, thereby avoiding the bias in parameter estimation and erroneous inference highlighted by Gormley and Matsa (2014) when using the traditional industry-mean adjustment method. Column 1 of Table 11 shows that media coverage remains negatively associated with bond offering yield spreads even after controlling for the industry $\times$ year fixed effects.

\section{TABLE 11}

\section{Alternative Media Measures}

Table 11 performs the robustness tests by introducing adjusted media coverage variables. The dependent variable is bond yield spreads. LAG_3M_MEDIA is the average of 3-month lagged media coverage. MEDIA_RES is the residual from the regression of media coverage against the variables affecting media coverage in Table 3 and other variables in Table 4. All variables, with the exception of media coverage, used in Table 4 are included in the regression as control variables. We control for industry $\times$ years fixed effects in all regressions to avoid the bias in controlling the industry effect. The $t$-values based on standard errors clustered at the issuer level are in parentheses, and ${ }^{*}{ }^{* *}$, and ${ }^{* * *}$ indicate the significance at the $10 \%, 5 \%$, and $1 \%$ levels, respectively.

\begin{tabular}{|c|c|c|c|}
\hline & 1 & 2 & 3 \\
\hline MEDIA & $\begin{array}{l}-0.165^{\star \star \star} \\
(-3.55)\end{array}$ & & \\
\hline LAG_3M_MEDIA & & $\begin{array}{l}-0.113^{\star \star \star} \\
(-3.25)\end{array}$ & \\
\hline MEDIA_RES & & & $\begin{array}{l}-0.166^{* * *} \\
(-3.60)\end{array}$ \\
\hline $\begin{array}{l}\text { Control variables } \\
\text { FF } 48 \text {-industry } \times \text { year fixed effects }\end{array}$ & $\begin{array}{l}\text { Yes } \\
\text { Yes }\end{array}$ & $\begin{array}{l}\text { Yes } \\
\text { Yes }\end{array}$ & $\begin{array}{l}\text { Yes } \\
\text { Yes }\end{array}$ \\
\hline $\begin{array}{l}\text { No. of obs. } \\
\text { Adj. } R^{2}\end{array}$ & $\begin{array}{l}3,901 \\
0.729\end{array}$ & $\begin{array}{l}3,901 \\
0.731\end{array}$ & $\begin{array}{l}3,901 \\
0.730\end{array}$ \\
\hline
\end{tabular}


Media coverage could also have a lagged influence due to a low information dissemination speed. To investigate this possibility, we use the average of 3-month lagged media coverage, LAG_3M_MEDIA, as an alternative explanatory variable in the yield spread regressions. Column 2 shows that our results are robust to the use of this lagged (predetermined) coverage variable. Furthermore, we investigate the robustness of results to the use of orthogonal (unexplained) media coverage, MEDIA_RES, which are the residuals from a regression of media coverage against its determinants (Table 3) and other variables affecting yield spreads (Table 4). The last column in Table 11 shows that media coverage coefficient remains highly significant and negative even after extracting the information from other control variables that may affect media coverage.

\section{Conclusions}

The business media perform the important function of disseminating information to investors. Previous studies have investigated the information dissemination role of media and its effects on stock returns, IPO performance, investment decisions, and governance. However, the role of media coverage in corporate financing decisions is much less known. Our study attempts to fill this gap by assessing the potential effect of media attention on a firm's cost of debt capital.

We document a strong negative relation between media coverage and the cost of debt. This finding supports the view that media coverage alleviates information frictions and enhances investor recognition and thus, reduces bond offering yield spreads. In addition, we find that the impact of media coverage works through multiple economic channels, such as information asymmetry, corporate governance, liquidity, and default risk. Our results show that the benefit of media coverage is larger for firms with fewer analysts, less reputable banks, lower institutional ownership and board and governance quality, smaller equity capitalization, younger age, lower liquidity, higher default risk, and less reliable accounting statements. More importantly, media coverage has a significant influence on bond offering yield spreads beyond the effects of these other firm attributes. Our results strongly suggest that media coverage is not a proxy for these variables or the other conventional determinants of the cost of debt capital. Overall, there is clear evidence that media coverage has a significant relation to a firm's cost of debt that is robust to different model specifications, information asymmetry measures, and controls. Our findings on the media coverage effect on the cost of debt suggest that the media can play an important role in corporate financing decisions and that it will be fruitful to examine the effects of media coverage on the cost of financing in other fixed-income securities and capital structure decisions.

\section{Appendix A. Variable Definitions and State-Level Number of Employees in the Newspaper Industry}

We provide below the definition of all variables used in this paper.

Data from FISD \& SDC

YIELD_SPREAD: The spread (in percentage) between the bond offering yield and the yield of the synthetic risk-free bond yield, which is calculated using the same coupons and principle as the corresponding corporate bond. 
YIELD: The bond offering yield (in percentage).

RATING: An ordinal number ranging from 0 for AAA bonds to 20 for $\mathrm{C}$ bonds (if Moody's rating is unavailable, we use the rating from $S \& P$ ).

MATURITY: Years to maturity of a bond. We take the natural logarithm transformation in the regression.

ISSUE_SIZE: The total amount of capital proceeds from bond issuance in million dollars. The natural logarithm of the total proceeds is used in the regression.

RELATIVE_SIZE: The total amount of capital proceeds from bond issuances divided by total assets of the issuer.

REPU_IVBANK: A dummy variable taking a value of 1 if the bonds are underwritten by reputable banks, and 0 otherwise. Following Fang (2005), the group of reputable banks includes Goldman Sachs, Merrill Lynch, Morgan Stanley, Salomon Brothers, CSFB, Lehman Brothers, JP Morgan, and DLJ.

GROSS_SPREAD: Gross spread, including the total underwriter fee, management fee, and selling concessions, divided by the issue size.

BOND_PAST_5Y: The size of bond offerings in the past 5 years. The natural logarithm of the total proceeds is used in the regression.

SEO_PAST_5Y: The size of publicly seasoned equity offerings in the past 5 years. The natural logarithm of the total proceeds is used in the regression.

COLLATERAL: A dummy variable taking a value of 1 if the bond has collateral requirements, and 0 otherwise.

\section{Data from LexisNexis}

MEDIA: The total number of newspaper articles in the month prior to the bond issuance day. We take the natural logarithm of 1 plus the total number of newspaper articles in the regression.

LAG_3M_MEDIA: The average of monthly media coverage from month $t-2$ to $t-4$ prior to the bond offering date.

MEDIA_RES: The residuals from the regression of media coverage against the variables affecting media coverage.

\section{Data from IBES}

ANALYSTS: The number of stock analysts issuing earnings forecasts. We take the natural logarithm of 1 plus the number of analysts in the regression.

DISPERSION: The dispersion of analysts' forecasts of 1-year EPS, measured by the standard deviation of analyst forecasts.

\section{Data from Compustat, CRSP \& NAIC}

FIRMSIZE: The total amount of assets in billion dollars. The natural logarithm of 1 plus the total asset is used in the regression.

LEVERAGE: The ratio of total liabilities divided by total assets.

AGE: The number of years elapsed since the year of the company's IPO. We use the natural logarithm of 1 plus the age in the regression.

EMPLOYEES: The number of employees, in thousands. We use the natural logarithm of 1 plus the number of employees in the regression.

SHAREHOLDERS: The number of common/ordinary shareholders, in thousands. We use the natural logarithm of 1 plus the number of shareholders in the regression. 
ROA: The ratio of net income over total assets.

MTB: The ratio of market value to book value of an asset, defined as market capitalization + total asset - book equity value over total asset.

RETURN: Average daily stock returns over the past 250 trading days (in percentage).

VOLATILITY: Standard deviation of daily stock returns over the past 250 trading days.

STOCK_LIQ: Taken from Amihud (2002), the illiquidity is measured by the daily absolute stock returns divided by trading volume. We take the natural logarithm and multiply it by -1 to convert it to a measure of liquidity; that is, a higher value of this measure corresponds to a higher level of liquidity. We compute this variable over a 1-year window prior to the offering date.

BOND_LIQ: Bond price impact is calculated based on transaction prices of all trades in the 1-year window prior to the offering date as

$$
10^{8} \times \frac{\left(\frac{\text { maximum price }- \text { minimum price }}{\text { average price }}\right)}{\text { total volume }},
$$

where maximum, minimum, and average prices denote the highest, lowest, and mean prices of trades, respectively, during the past year (see Kalimipalli and Nayak (2012)). Price impacts are averaged across all of a firm's outstanding bonds over a 1-year window. We then take the natural logarithm and multiply it by -1 to come up with the issuer's bond liquidity.

BIG_AUDITOR: An indicator variable that is set to 1 if the firm hires an auditor from the Big 6 group (see Fang (2005)), which shrank to the Big 5 in 1998, and to the Big 4 in 2002 after the downfall of Arthur Andersen, and 0 otherwise.

EDF: Expected default frequency estimated from Merton's structural model.

Z_SCORE: We follow Graham et al. (2008) and Lemmon and Roberts (2010) to use the modified Altman's Z-score.

\section{Data from BoardEx, Thomson $13 F$ \& DealScan}

BOARD_SIZE: The number of directors on a board. We use the natural logarithm of 1 plus the age in the regression.

BOARD_IND: The number of independent directors scaled by the total number of directors.

ISS_INDEX: Following Chung et al. (2010), we use the 24 governance standards compiled by Institutional Shareholder Services (ISS) and award 1 point for each governance standard that is met. The ISS index is a broader corporate governance measure than that of Gompers, Ishii, and Metrick (GIM (2003)), which primarily captures antitakeover provisions in a firm's charter, its bylaws, and state law.

INSTITUTIONAL: The stock ownership of institutional investors in percentage of total shares.

SYNDICATE_SIZE: The number of syndicate lenders in the syndicated debt contract available on DealScan. We use the natural logarithm of 1 plus the number of syndicate lenders in the regression.

SYNDICATE_REPU: A dummy variable that takes a value of 1 if the issuer's leading bank in the syndicated loan ranks among the top 10 banks in market share over the past 3-year horizon, and 0 otherwise. 


\section{Appendix B}

TABLE B1

Distribution by State for the Number of Employees in the Newspaper Industry

Table B1 reports state-level statistics of the number of employees and state population in the newspaper industry. We manually collect the data from the Bureau of Labor Statistics: https://www.bls.gov/oes/current/oes273022.htm. We restrict our analysis to the item labeled Reporters and Correspondents, who collect and analyze facts about newsworthy events by interview, investigation, or observation, and report and write stories for newspapers, news magazines, radio, or television. State populations come from census estimates: https://census.gov/data/tables/time-series/demo/popest/ intercensal-1990-2000-state-and-county-totals.html. No. per 1,000 is the number of reporters and correspondents per capita (1,000 people).

\begin{tabular}{|c|c|c|c|c|c|c|c|c|c|}
\hline ST & State & Employees & Population & $\begin{array}{c}\text { No. per } \\
1,000 \\
\end{array}$ & $\underline{\mathrm{ST}}$ & State & Employees & Population & $\begin{array}{c}\text { No. per } \\
1,000 \\
\end{array}$ \\
\hline$A L$ & Alabama & 570 & $4,367,935$ & 0.130 & NJ & New Jersey & 1,650 & $8,218,808$ & 0.201 \\
\hline $\mathrm{AK}$ & Alaska & 180 & 612,968 & 0.294 & NM & New Mexico & 230 & $1,774,839$ & 0.130 \\
\hline$A Z$ & Arizona & 1,020 & $4,736,990$ & 0.215 & NY & New York & 7,960 & $18,656,546$ & 0.427 \\
\hline AR & Arkansas & 430 & $2,601,090$ & 0.165 & NC & North Carolina & 1,260 & $7,656,825$ & 0.165 \\
\hline $\mathrm{CA}$ & California & 5,120 & $32,486,010$ & 0.158 & ND & North Dakota & 330 & 649,716 & 0.508 \\
\hline $\mathrm{CO}$ & Colorado & 740 & $4,018,293$ & 0.184 & $\mathrm{OH}$ & Ohio & 2,360 & $11,277,357$ & 0.209 \\
\hline $\mathrm{CT}$ & Connecticut & 680 & $3,349,348$ & 0.203 & OK & Oklahoma & 550 & $3,372,917$ & 0.163 \\
\hline DE & Delaware & 100 & 751,487 & 0.133 & OR & Oregon & 800 & $3,304,310$ & 0.242 \\
\hline DC & D. of Columbia & 1,660 & 567,736 & 2.924 & PA & Pennsylvania & 2,910 & $12,227,814$ & 0.238 \\
\hline $\mathrm{FL}$ & Florida & 2,300 & $15,186,304$ & 0.151 & $\mathrm{RI}$ & Rhode Island & 220 & $1,025,353$ & 0.215 \\
\hline $\mathrm{GA}$ & Georgia & 1,150 & $7,685,099$ & 0.150 & SC & South Carolina & 510 & $3,859,696$ & 0.132 \\
\hline $\mathrm{HI}$ & Hawaii & 350 & $1,211,640$ & 0.289 & SD & South Dakota & 250 & 744,223 & 0.336 \\
\hline ID & Idaho & 260 & $1,228,520$ & 0.212 & $\mathrm{TN}$ & Tennessee & 1,050 & $5,499,233$ & 0.191 \\
\hline IL & Illinois & 3,280 & $12,185,715$ & 0.269 & TX & Texas & 2,320 & $19,740,317$ & 0.118 \\
\hline IN & Indiana & 1,030 & $5,955,267$ & 0.173 & UT & Utah & 280 & $2,119,784$ & 0.132 \\
\hline $\mathrm{IA}$ & lowa & 360 & $2,891,119$ & 0.125 & VT & Vermont & 220 & 597,239 & 0.368 \\
\hline KS & Kansas & 880 & $2,635,292$ & 0.334 & VA & Virginia & 1,240 & $6,829,183$ & 0.182 \\
\hline KY & Kentucky & 700 & $3,952,747$ & 0.177 & WA & Washington & 1,180 & $5,674,747$ & 0.208 \\
\hline LA & Louisiana & 630 & $4,421,071$ & 0.142 & WV & West Virginia & 190 & $1,819,113$ & 0.104 \\
\hline ME & Maine & 290 & $1,254,774$ & 0.231 & WI & Wisconsin & 1,360 & $5,266,213$ & 0.258 \\
\hline MD & Maryland & 750 & $5,157,328$ & 0.145 & WY & Wyoming & 150 & 489,451 & 0.306 \\
\hline MA & Massachusetts & 1,300 & $6,226,058$ & 0.209 & & & & & \\
\hline Ml & Michigan & 1,250 & $9,809,051$ & 0.127 & & & & & \\
\hline MN & Minnesota & 950 & $4,763,390$ & 0.199 & & & & & \\
\hline MS & Mississippi & 410 & $2,777,004$ & 0.148 & & & & & \\
\hline $\mathrm{MO}$ & Missouri & 1,090 & $5,481,193$ & 0.199 & & & & & \\
\hline MT & Montana & 320 & 889,865 & 0.360 & & & & & \\
\hline NE & Nebraska & 420 & $1,686,418$ & 0.249 & & & & & \\
\hline NV & Nevada & 230 & $1,764,104$ & 0.130 & & & & & \\
\hline $\mathrm{NH}$ & New Hampshire & 370 & $1,189,425$ & 0.311 & & & & & \\
\hline
\end{tabular}

\section{References}

Ailawadi, K. L.; D. R. Lehmann; and S. A. Neslin. "Revenue Premium as an Outcome Measure of Brand Equity." Journal of Marketing, 67 (2003), 1-17.

Al Guindy, M. "Corporate Twitter Use and Cost of Capital." Working Paper, Social Science Research Network (2016).

Amihud, Y. "Illiquidity and Stock Returns: Cross-Section and Time-Series Effects." Journal of Financial Markets, 5 (2002), 31-56.

Anderson, R. C.; S. A. Mansi; and D. M. Reeb. "Board Characteristics, Accounting Report Integrity, and the Cost of Debt." Journal of Accounting and Economics, 37 (2004), 315-342.

Andrade, S. C.; G. Bernile; and F. M. Hood. "SOX, Corporate Transparency, and the Cost of Debt." Journal of Banking and Finance, 38 (2014), 145-165.

Anthony, J. H., and K. Ramesh. "Association between Accounting Performance Measures and Stock Prices: A Test of the Life Cycle Hypothesis." Journal of Accounting and Economics, 15 (1992), 203-227.

Baloria, V., and J. Heese. "The Effects of Media Slant on Firm Behavior." Journal of Financial Economics, 129 (2018), 184-202.

Barth, M. R.; W. R. Landsman; and D. J. Taylor. "The JOBS Act and Information Uncertainty in IPO Firms." Accounting Review, 92 (2017), 25-47.

Beatty, R., and J. Ritter. "Investment Banking, Reputation, and the Underpricing of Initial Public Offerings.” Journal of Financial Economics, 15 (1986), 213-232. 
Bharath, S., and A. Dittmar. "Why Do Firms Use Private Equity to Opt out of Public Markets?" Review of Financial Studies, 23 (2010), 1771-1818.

Bhojraj, S., and P. Sengupta. "Effect of Corporate Governance on Bond Ratings and Yields: The Role of Institutional Investors and Outside Directors.” Journal of Business, 76 (2003), 455-475.

Biggerstaff, L.; D. C. Cicero; and A. Puckett. "Suspect CEOs, Unethical Culture, and Corporate Misbehavior.” Journal of Financial Economics, 117 (2015), 98-121.

Blankespoor, E.; G. S. Miller; and H. D. White. "The Role of Dissemination in Market Liquidity: Evidence from Firms' Use of Twitter.” Accounting Review, 89 (2014), 79-112.

Blume, M. E.; F. Lim; and A. C. MacKinlay. "The Declining Credit Quality of US Corporate Debt: Myth or Reality?” Journal of Finance, 53 (1998), 1389-1413.

Bongaerts, D.; F. de Jong; and J. Driessen. "An Asset Pricing Approach to Liquidity Effects in the Corporate Bond Market.” Review of Financial Studies, 30 (2017), 1229-1269.

Boone, A. L., and J. T. White. "The Effect of Institutional Ownership on Firm Transparency and Information Production.” Journal of Financial Economics, 117 (2015), 508-533.

Borisova, G., and W. L. Megginson. "Does Government Ownership Affect the Cost of Debt? Evidence from Privatization.” Review of Financial Studies, 24 (2011), 2693-2737.

Bushee, B. J.; J. E. Core; W. Guay; and S. J. Hamm. "The Role of the Business Press as an Information Intermediary." Journal of Accounting Research, 48 (2010), 1-19.

Bushee, B. J., and C. F. Noe. "Corporate Disclosure Practices, Institutional Investors, and Stock Return Volatility." Journal of Accounting Research, 38 (2000), 171-202.

Cai, N. K.; J. Helwege; and A. Warga. "Underpricing in the Corporate Bond Market." Review of Financial Studies, 20 (2007), 2021-2046.

Campbell, J. Y., and G. B. Taksler. "Equity Volatility and Corporate Bond Yields.” Journal of Finance, 58 (2003), 2321-2350.

Cao, J., and J. Lerner. "The Performance of Reverse Leveraged Buyouts.” Journal of Financial Economics, 91 (2009), 139-157.

Cassar, G.; C. D. Ittner; and K. S. Cavalluzzo. "Alternative Information Sources and Information Asymmetry Reduction: Evidence from Small Business Debt." Journal of Accounting and Economics, 59 (2014), 242-263.

Chan, L. H.; C. W. Chen; and T. Y. Chen. "The Effects of Firm-Initiated Clawback Provisions on Bank Loan Contracting." Journal of Financial Economics, 110 (2013), 659-679.

Chan, W. S. "Stock Price Reaction to News and No-News: Drift and Reversal after Headlines." Journal of Financial Economics, 70 (2003), 223-260.

Chen, S.; M. L. DeFond; and C. W. Park. "Voluntary Disclosure of Balance Sheet Information in Quarterly Earnings Announcements." Journal of Accounting and Economics, 33 (2002), 229-251.

Chung, K. H.; J. Elder; and J. C. Kim. "Corporate Governance and Liquidity.” Journal of Financial and Quantitative Analysis, 45 (2010), 265-291.

Chung, K. H.; T. H. McInish; R. A. Wood; and D. J. Wyhowski. "Production of Information, Information Asymmetry, and the Bid-Ask Spread: Empirical Evidence from Analysts' Forecasts." Journal of Banking and Finance, 19 (1995), 1025-1046.

Chung, K. H., and H. Zhang. "Corporate Governance and Institutional Ownership.” Journal of Financial and Quantitative Analysis, 46 (2011), 247-273.

Core, J. E.; W. R. Guay; and T. O. Rusticus. "Does Weak Governance Cause Weak Stock Returns? An Examination of Firm Operating Performance and Investors' Expectations." Journal of Finance, 61 (2006), 655-687.

Dai, L.; J. Parwada; and B. Zhang. "The Governance Effect of the Media's News Dissemination Role: Evidence from Insider Trading.” Journal of Accounting Research, 53 (2015), 331-366.

Deephouse, D. L. "Media Reputation as a Strategic Resource: An Integration of Mass Communication and Resource-Based Theories.” Journal of Management, 26 (2000), 1091-1112.

Dhaliwal, D.; C. Hogan; R. Trezevant; and M. Wilkins. "Internal Control Disclosures, Monitoring, and the Cost of Debt." Accounting Review, 86 (2011), 1131-1156.

Diamond, D. W., and R. E. Verrecchia. "Disclosure, Liquidity, and the Cost of Capital." Journal of Finance, 46 (1991), 1325-1359.

Duffie, D., and D. Lando. "Term Structure of Credit Spreads with Incomplete Accounting Information." Econometrica, 69 (2001), 633-664.

Dunbar, C. "Factors Affecting Investment Bank Initial Public Offering Market Share." Journal of Financial Economics, 55 (2000), 3-41.

Dyck, A.; A. Morse; and L. Zingales. "Who Blows the Whistle on Corporate Fraud?" Journal of Finance, 65 (2010), 2213-2253.

Dyck, A.; N. Volchkova; and L. Zingales. "The Corporate Governance Role of the Media: Evidence from Russia.” Journal of Finance, 63 (2008), 1093-1135. 
Dyck, A., and L. Zingales. "The Corporate Governance Role of the Media." Working Paper, Harvard University (2002).

Dyck, A., and L. Zingales. "The Media and Asset Prices." Working Paper, Harvard University (2003).

Easley, D., and M. O'Hara. "Information and the Cost of Capital." Journal of Finance, 59 (2004), 1553-1583.

Fang, L. "Investment Bank Reputation and the Price and Quality of Underwriting Services." Journal of Finance, 60 (2005), 2729-2761.

Fang, L., and J. Peress. "Media Coverage and the Cross-Section of Stock Returns." Journal of Finance, 64 (2009), 2023-2052.

Fields, L. P.; D. R. Fraser; and A. Subrahmanyam. "Board Quality and the Cost of Debt Capital: The Case of Bank Loans.” Journal of Banking and Finance, 36 (2012), 1536-1547.

Fombrun, C., and M. Shanley. "What's in a Name? Reputation Building and Corporate Strategy." Academy of Management Journal, 33 (1990), 233-258.

Gao, X., and J. R. Ritter. "The Marketing of Seasoned Equity Offerings.” Journal of Financial Economics, 97 (2010), 33-52.

Gompers, P.; J. Ishii; and A. Metrick. "Corporate Governance and Equity Prices." Quarterly Journal of Economics, 118 (2003), 107-156.

Gormley, T. A., and D. A. Matsa. "Common Errors: How to (and not to) Control for Unobserved Heterogeneity." Review of Financial Studies, 27 (2014), 617-661.

Graham, J. R.; S. Li; and J. Qiu. "Corporate Misreporting and Bank Loan Contracting." Journal of Financial Economics, 89 (2008), 44-61.

Grossman, S. J., and J. E. Stiglitz. "On the Impossibility of Informationally Efficient Markets.” American Economic Review, 70 (1980), 393-408.

Gurkaynak, R.; B. Sack; and J. Wright. "The U.S. Treasury Yield Curve: 1961 to the Present.” Journal of Monetary Economics, 54 (2007), 2291-2304.

Healy, P. M.; A. P. Hutton; and K. G. Palepu. "Stock Performance and Intermediation Changes Surrounding Sustained Increases in Disclosure." Contemporary Accounting Research, 16 (1999), $485-520$.

Heckman, J. J. “Sample Selection Bias as a Specification Error.” Econometrica, 47 (1979), 153-161.

Hillert, A., and M. Ungeheuer. "Ninety Years of Media Coverage and the Cross-Section of Stock Returns." Working Paper, University of Mannheim (2016).

Joe, J.; H. Louis; and D. Robinson. "Managers' and Investors' Responses to Media Exposure of Board Ineffectiveness." Journal of Financial and Quantitative Analysis, 44 (2009), 579-605.

Kalimipalli, M., and S. Nayak. "Idiosyncratic Volatility vs. Liquidity? Evidence from the US Corporate Bond Market.” Journal of Financial Intermediation, 21 (2012), 217-242.

Kempf, E.; A. Manconi; and O. Spalt. "Distracted Shareholders and Corporate Actions." Review of Financial Studies, 30 (2017), 1660-1695.

Kirk, M. P., and J. D. Vincent. "Professional Investor Relations Within the Firm.” Accounting Review, 89 (2014), 1421-1452.

Klock, M. S.; S. A. Mansi; and W. F. Maxwell. "Does Corporate Governance Matter to Bondholders?" Journal of Financial and Quantitative Analysis, 40 (2005), 693-719.

Kogan, L., and D. Papanikolaou. "Growth Opportunities, Technology Shocks, and Asset Prices.” Journal of Finance, 69 (2014), 675-718.

Lemmon, M., and M. R. Roberts. "The Response of Corporate Financing and Investment to Changes in the Supply of Credit." Journal of Financial and Quantitative Analysis, 45 (2010), 555-587.

Lin, H.; J. Wang; and C. Wu. "Liquidity Risk and Expected Corporate Bond Returns." Journal of Financial Economics, 99 (2011), 628-650.

Liu, B., and J. McConnell. "The Role of the Media in Corporate Governance: Do the Media Influence Managers' Capital Allocation Decisions?” Journal of Financial Economics, 110 (2013), 1-17.

Liu, L. X.; A. E. Sherman; and Y. Zhang. "The Long-Run Role of the Media: Evidence from Initial Public Offerings.” Management Science, 60 (2014), 1945-1964.

Lowry, M.; M. Officer; and G. W. Schwert. "The Variability of IPO Initial Returns." Journal of Finance, 65 (2010), 425-465.

Mansi, S. A.; W. F. Maxwell; and D. P. Miller. "Does Auditor Quality and Tenure Matter to Investors? Evidence from the Bond Market." Journal of Accounting Research, 42 (2004), 755-793.

Mansi, S. A.; W. F. Maxwell; and D. P. Miller. "Analyst Forecast Characteristics and the Cost of Debt." Review of Accounting Studies, 16 (2011), 116-142.

Merton, R. C. "On the Pricing of Corporate Debt: The Risk Structure of Interest Rates." Journal of Finance, 29 (1974), 449-470.

Merton, R. C. "A Simple Model of Capital Market Equilibrium with Incomplete Information.” Journal of Finance, 42 (1987), 483-510. 
Michaely, R., and M. R. Roberts. "Corporate Dividend Policies: Lessons from Private Firms.” Review of Financial Studies, 25 (2012), 711-746.

Pan, Y.; T. Y. Wang; and M. S. Weisbach. "Learning about CEO Ability and Stock Return Volatility." Review of Financial Studies, 28 (2015), 1623-1666.

Peress, J. "The Media and the Diffusion of Information in Financial Markets: Evidence from Newspaper Strikes.” Journal of Finance, 69 (2014), 2007-2043.

Pittman, J. A., and S. Fortin. "Auditor Choice and the Cost of Debt Capital for Newly Public Firms." Journal of Accounting and Economics, 37 (2004), 113-136.

Rock, K. "Why New Issues are Underpriced." Journal of Financial Economics, 15 (1986), 187-212.

Rosenbaum, P. R., and D. B. Rubin. "The Central Role of the Propensity Score in Observational Studies for Causal Effects." Biometrika, 70 (1983), 41-55.

Solomon, D. H.; E. Soltes; and D. Sosyura. "Winners in the Spotlight: Media Coverage of Fund Holdings as a Driver of Flows." Journal of Financial Economics, 113 (2014), 53-72.

Staiger, D., and J. H. Stock. "Instrumental Variables Regression with Weak Instruments." Econometrica, 65 (1997), 557-586.

Stiglitz, J. E., and A. Weiss. "Credit Rationing in Markets with Imperfect Information." American Economic Review, 71 (1981), 393-410.

Tetlock, P. C. "Giving Content to Investor Sentiment: The Role of Media in the Stock Market." Journal of Finance, 62 (2007), 1139-1168.

Tetlock, P. C. "Does Public Financial News Resolve Asymmetric Information?" Review of Financial Studies, 23 (2010), 3520-3557.

Tetlock, P. C.; M. Saar-Tsechansky; and S. Macskassy. "More than Words: Quantifying Language to Measure Firms' Fundamentals.” Journal of Finance, 63 (2008), 1437-1467.

Veldkamp, L. L. "Media Frenzies in Markets for Financial Information." American Economic Review, 96 (2006), 577-601.

Vlastakis, N., and R. N. Markellos. "Information Demand and Stock Market Volatility." Journal of Banking and Finance, 36 (2012), 1808-1821.

Yu, F. "Accounting Transparency and the Term Structure of Credit Spreads." Journal of Financial Economics, 75 (2005), 53-84.

Zhang, X. "Information Uncertainty and Stock Returns.” Journal of Finance, 61 (2006), 105-137. 